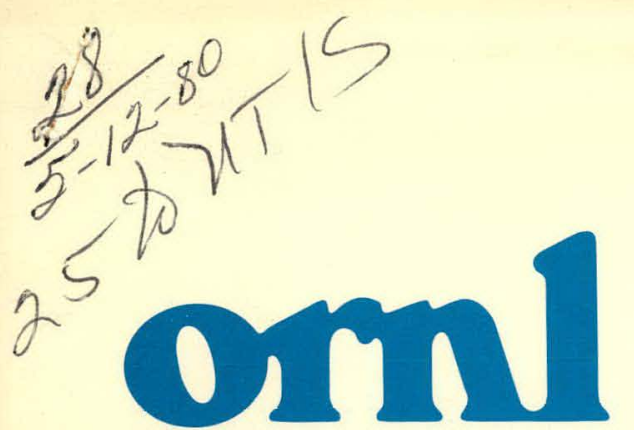

OAK

RIDGE

NATIONAL

LABORATORY

UNION

CARBIDE

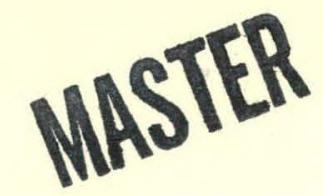

ORNL/CON-39

\section{Energy and Cost Analysis of Commercial Building Shell Characteristics and Operating Schedules}

\author{
William S. Johnson \\ F. E. Pierce
}

OPERATED BY

UNION CARBIDE CORPORATION FOR THE UNITED STATES DEPARTMENT OF ENERGY 


\section{DISCLAIMER}

This report was prepared as an account of work sponsored by an agency of the United States Government. Neither the United States Government nor any agency Thereof, nor any of their employees, makes any warranty, express or implied, or assumes any legal liability or responsibility for the accuracy, completeness, or usefulness of any information, apparatus, product, or process disclosed, or represents that its use would not infringe privately owned rights. Reference herein to any specific commercial product, process, or service by trade name, trademark, manufacturer, or otherwise does not necessarily constitute or imply its endorsement, recommendation, or favoring by the United States Government or any agency thereof. The views and opinions of authors expressed herein do not necessarily state or reflect those of the United States Government or any agency thereof. 


\section{DISCLAIMER}

Portions of this document may be illegible in electronic image products. Images are produced from the best available original document. 
Printed in the United States of America. Available from National Technical Information Service

U.S. Department of Commerce

5285 Port Royal Road, Springfield, Virginia 22161

NTIS price codes-Printed Copy: A04 Microfiche A01

This report was prepared as an account of work sponsored by an agency of the United States Government. Neither the United States Government nor any agency thereof, nor any of their employees, makes any warranty, express or implied, or assumes any legal liability or responsibility for the accuracy, completeness, or usefulness of any information, apparatus, product, or process disclosed, or represents that its use would not infringe privately owned rights. Reference herein tn any specific commercial product, process, or service by trade name, trademark, manufacturer, or otherwise, does not necessarily constitute or imply its endorsement, recommendation, or favoring by the United States Government or any agency thereof. The views and opinions of authors expressed herein do not necessarily state or reflect those of the United States Government or any agency thereof. 
Contract No. W-7405-eng-26

ENERGY DIVISION

ENERGY AND COST ANALYSIS OF COMMERCIAL BUILDING SHELL CHARACTERISTICS AND OPERATING SCHEDULES

William S. Johnson*

F. E. Pierce ${ }^{* *}$

Date Published: April 1980
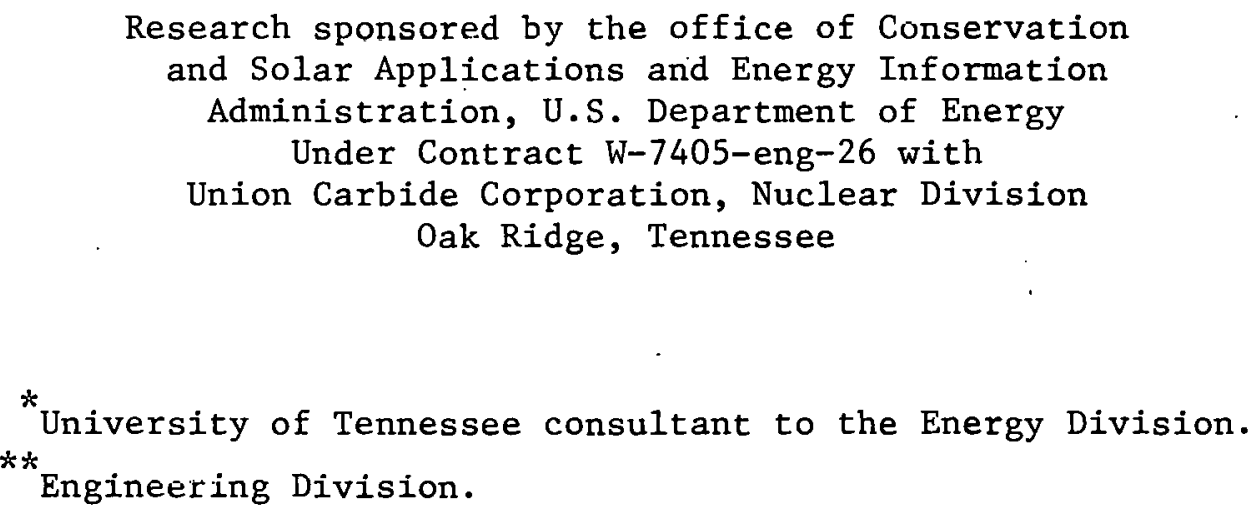

OAK KIDGE NATTONAL LABORATORY

Oak Ridge, Tennessee 37830

operated by

UNION CARBIDE CORPORATION

for the

DEPARTMENT OF ENERGY

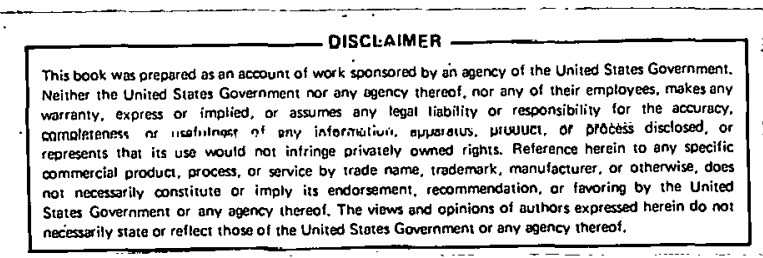




\section{OTHER REPORTS IN THIS SERIES}

1. J. Jackson, An Econometric-Engineering Analysis of Federal Energy Conservation Programs in the Commercial Sector, ORNL/CON-30, January 1979.

2. S. Cohn, Fuel Choice and Aggregate Energy Demand in the Commercial Sector, ORNL/CON-27, December 1978.

3. J. Jackson, et al., The Commercial Demand for Energy: A Disaggregated Approach, ORNL/CON-15, April 1978.

4. J. Jackson and W. Johnson, Commercial Energy Use: Disaggregation by Fuel, Building Type, and End Use, ORNL/CON-14, February 1978. 
TABLE OF CONTENTS

$\underline{\text { Page }}$

ACKNOWLEDGEMENTS . . . . . . . . . . . . . . . . . v v

ABSTRACT .......................... vi

1. INTRODUCTION ...................... . . . 1

2. METHOD OF APPROACH . . . . . . . . . . . . . . . 3

Building input to NECAP code . . . . . . . . . . . . 5

Energy conservation measures . . . . . . . . . . . . 7

3. BUILDING DESCRIPTIONS . . . . . . . . . . . . . . . 11

Wall and roof construction . . . . . . . . . . . . 11

Hospital . . . . . . . . . . . . . . . . 11

Office ........................ . . 15

Educational . . . . . . . . . . . . . . . . 21

Retall-wholesale . . . . . . . . . . . . . . 26

4. RESULTS . . . . . . . . . . . . . . . . . . 28

Hospital . . . . . . . . . . . . . . . . . 30

Office . . . . . . . . . . . . . . . . . . 34

Educational facility . . . . . . . . . . . . . . 37

Retail-wholesale . . . . . . . . . . . . . . 41

5. SUMMARY OF RESULTS . . . . . . . . . . . . . . . 44

6. ENERGY SAVINGS AND CAPITAL COSTS . . . . . . . . . . 45

REFERENCES . . . . . . . . . . . . . . . . . 56

APPENDIX . . . . . . . . . . . . . . . . . 57 
THIS PAGE

WAS INTENTIONALLY

LEFT BLANK 


\section{ACKNOWLEDGMENTS}

The authors gratefully acknowledge the careful review of this report by Ken Corum, Dennis $0^{\prime}$ Neal, Tom Fisher, Jeff Christian, John Devaney, and Eric Hirst. We are also indebted to J. H. Corley for many helpful suggestions and comments during the study. 


\section{THIS PAGE}

\section{WAS INTENTIONALLY LEFT BLANK}




\section{ABSTRACT}

This report considers eight prototypical commercial buildings and presents estimates of the energy savings realized from various conservation measures. For each of four building types (hospital, office, educational, and retail) two building designs representative of both preand post-embargo construction were analyzed. This study is part of an ongoing program at Oak Ridge National Laboratory to develop an engineeringeconomic model to forecast annual energy use in the commercial sector of the United States. This particular study was undertaken to define relationships among energy conservation measures, energy savings and capital costs. Buildings were modelled and analyzed using NECAP (NASA Energy-Cost Analysis Program) based on hourly weather data in Kansas City (selected as typical of the entire country).

Energy conservation measures considered in this study include night and weekend thermostat setback, reduction in ventilation, reduction in lighting, window alterations (shading, dual panes, and size reduction), economizer cycle, reset of supply temperature based on zone demand, and improvements in equipment efficiencies. Résults indicate energy savings as a function of the capital cost of each energy conservation measure for each of the eight buildings considered. 


\section{INTRODUCTION}

The commercial sector consumes a small but rapidly increasing fraction of the nation's total energy use. For example, the commercial sector consumed around $10 \%$ of the total in 1950 and its share had increased to more than $13 \%$ by 1975 . This trend is expected to continue in the future because of the increasing demand for services relative to the total output of the economy.

This study is part of an ongoing project at ORNL to develop a comprehensive engineering/economic model of energy use in the commercial sector. The model forecasts future energy use based on fuel type, building shell characteristics, building operating characteristics, HVAC* systems, etc.

The purpose of this work is to determine the effect of various energy conservation measures on energy use in commercial buildings. Conservation measures for exlsting buildings along with those which may be employed in new building construction (ASHRAE 90-75 standard $^{1}$ for energy efficient construction) were examined in this study.

Jackson and Johnson ${ }^{2}$ divided the commcreial sector floorspace into ten building types and also developed total national commercial fuel use for electricity, gas, oil, and "other" fuels for the years 1965-1975. Using a unique disaggregation approach, they determined energy use by fuel typc and building type for each of five end-uses: space heating, space cooling, water hcating, 11ghting and other. Table 1 lists

\footnotetext{
${ }^{*}$ Heating, Ventilating, and A1r Conditioning.
} 
Table 1. Floorspace and commercial energy use by building type, $1975^{\alpha}$

\begin{tabular}{|c|c|c|c|c|}
\hline Building type & $\begin{array}{l}\text { Energy use } \\
\left(10^{15} \mathrm{Btu}\right)\end{array}$ & $\begin{array}{l}\text { Percentage of } \\
\text { total energy use }\end{array}$ & $\begin{array}{l}\text { Floorspace } \\
\left(10^{6} \mathrm{ft}^{2}\right)\end{array}$ & $\begin{array}{l}\text { Percentage of } \\
\text { total floorspace }\end{array}$ \\
\hline Retail-wholesale & $2 . \approx 0$ & 23.9 & 5239.0 & 18.5 \\
\hline Educational & $1 . .7$ & 19.3 & 6561.0 & 23.2 \\
\hline Office-public & 1.84 & 20.0 & 5346.0 & 18.9 \\
\hline Health & 1.08 & 11.7 & 1993.0 & 7.1 \\
\hline Hotel-motel & 0.56 & 6.1 & 1444.0 & 5.1 \\
\hline Warehouses & 0.32 & 3.5 & 2290.0 & 8.1 \\
\hline Religious & 0.26 & 2.8 & 1404.0 & 5.0 \\
\hline Garages and service stations & 0.09 & 1.0 & 617.6 & 2.2 \\
\hline Other & 1.08 & 11.7 & 3382.0 & 11.9 \\
\hline Total & 9.20 & 100.0 & $28,276.6$ & 100.0 \\
\hline
\end{tabular}

$a_{\text {From Ref. } 2 \text {. }}$ 
floorspace and total energy consumed for each end use and building type for the year 1975. From this table, it is observed that over $70 \%$ of al1 energy use is consumed by just 4 building types; retail-wholesale, office, health care, and educational with no other single building type consuming more than $7 \%$ of the total. Consequently, this study focused on these four building types.

Section 2 of this report discusses the general method of approaching the problem, Sect. 3 gives a description of buildings analyzed, Sect. 4 summarizes the potential energy savings for each building type, Sect. 5 gives estimates of potential national energy savings, and Sect. 6 gives energy savings as a function of estimated capital costs.

\section{METHOD OF APPROACH}

To evaluate the effect of various energy conservation measures in the commercial sector, several buildings were selected and analyzed to exhibit energy use typical of an "average" building of that particular type.

Each building was analyzed with the $\mathrm{NECAP}^{3}$ computer program which determines energy use from an hour-by-hour analysis using hourly weather information. The NECAP program allows detailed building construction, thermostat type and setting and any one of several HVAC systems to be included in the model.

Weather data for Kansas City in the year 1955 was selected for use in the study because it had close to the national average number of heating degree days and, when analyzed with the various model buildings, 
produced both heating and cooling energy usage most representative of the results produced in Ref. 2. Other cities considered were Louisville, Indianapolis, and Washington, D.C.*

For each building type, two different buildings with the same geometric configuration and orientation were considered. First a building construction typical of the pre-embargo period (prior to the 1973 oil embargo) was modelled. Such buildings emphasized appearance and comfort to the detriment of energy savings. The second construction for each building type was designed with energy conservation as a prime consideration and many of the requirements of the ASHRAE 90-75 standard were included. This required such changes as additional insulation in walls and roof and a more efficient chiller. In addition, other changes representing more energy-conscious design included a more efficient HVAC ducting system (variable air volume if practical), reduced outside air, energy recovery systems, etc.

Fur cach of the two buildings representing a single building type, energy conservation measures considered in this study were those which do not require extensive modifications to the building shell or HVAC system (such as major modification of the ducting system). Several measures fall into the category of energy management: thermostat setback, reduction of internal loads such as lighting, and reduction in outside

\footnotetext{
*There is little information in the literature that allows the selection of an average building or of weather data typical of the entire country (such averages may not even exist), although time and budget constraints did not allow the analysis of more than two buildings of a given type or more than one weather location.
} 
ventilation air. Measures requiring only minor building modifications included addition of internal window shading, addition of insulation, dual pane windows, etc.

Lyman $^{4}$ studied energy use in office buildings and hospitals incorporating several different HVAC systems and conservation measures. He employed the same building models developed for this study and incorporatcd various HVAC systems (dual duct, variable air volume, multizone, fancoil units, etc.) and several energy conservation measures (economizer cycle, heat recovery, double bundle heat exchangers, improved equipment efficiency, solar supplemental heating, etc.). Lyman!s study considered only the "base case" buildings (no thermostat setback, etc.), but included both pre- and post-embargo building types.

The combination of the study by Lyman $^{4}$ and this study covers most of the reasonable energy conservation options for offices and hospitals. Continuing work will extend this to schools and retail buildings.

\section{Building input to NECAP code}

To minimize computing tiüte, some simplifications were made to model the building shell using the NECAP code. These are discussed in the following paragraphs.

First, it was assumed that there is no shading on the huilding. This simplified input, reduced computing time and consequently, influenccd the absolute value of building energy use. However, it should have little effect when an energy conservation measure is evaluated relative to the base case. 
The number of heating/cooling zones in each building was minimized because computing time is directly proportional to the number of zones. In multi-story buildings, zones were considered to extend from floor to roof with intermediate floors modeled by increasing the input value of weight of furnishings to produce an equivalent thermal inertia in each zone.

The walls, which were modeled as delayed surfaces, ${ }^{*}$ were all of the same construction which reduced the required number of sets of response factors. This simplification along with allowing the zones to extend from the ground floor to the roof also resulted in a minimum number of delayed surfaces. Minimizing the number of delayed surfaces simplifies the input and results in shorter run times.

Windows were considered to be a single continuous strip around the building. This considerably simplified the input required by NECAP. Based upon the previously discussed assumptions of no shading and single multi-story zones, continuous windows ohould have minimal influence on the results. Doors are assumed to be of glass and are therefore included in the window area.

Operating schedules for people, lights, and equipment are the same for each zone in the office building. This was possible because the use characteristics of the zones were similar. The other buildings (hospital, school, and retail-wholesale), however, contained zones with different use characteristics and separate sets of schedules were required for

\footnotetext{
* Delayed surfaces are those which store energy, producing thermal inertia.
} 
each zone; also, in șome cases different schedules were used for people, lights, and equipment in each zone.

Energy conservation measures

Energy conservation measures for a particular building were primarily those which required minimal capital investment and as a consequence, most are operational in nature. A brief discussion of each measure follows.

Thermostat setback (night and weekend shutdown)

The thermostat in the baseline case is the linear proportional type which operates the HVAC system continuously as zone.temperatures vary between upper and lower set limits. Maximum cooling occurs at the high limit and maximum heating at the low limit with a linear variation of heating or cooling in between the temperature limits. To assess the energy savings possible when the system is turned off during unoccupied periods, the thermostat was changed to a combination linear and nn-nff type. The linear type was used from the pre-occupied warm-up or cooldown period through the early evening hours and the on-off type was used for the remainder of the workday. For non-work days, such as weekends, holidays, etc., the on-off thermostat was used exclusively. The on=off thermostal requires no heating or cooling when the zone temperature is within the prescribed set limits, and full heating and cooling are delivered when the zone temperature is at or below the lower setpoint and at or above the uiper setpoint, respectively. When the 
on-off thermostat is used, the low limit must be high enough to prevent freezing temperatures in the zone.

Reduced lighting

In pre-embargo years, many buildings were designed with uniform illumination throughout the building. Consequently, a careful survey of many buildings will yield lamps which may be removed or reduced in wattage with little or no effect on tasks to be done within the building. Also conversion from incandescent to fluorescent fixtures can produce significant energy savings. Savings are primarily in summer cooling which is normally greater than the additional winter heating required. The additional winter heating is normally fossil fuel heat so that electricity is replaced by fossil fuel during the heating season.

Reduced ventilation

The amount of outside ventilation air has a significant impact on energy use since it must be brought to inside temperature by the HVAC system. In pre-embargo years many buildings were designed to operate with ventilation rates in excess of the ASHRAE $62-73^{5}$ so that reductions in outside air may be a realistic conservation measure for many existing buildings.

Ventilation rates can be reduced to a level that is sufficient to meet the oxygen and carbon dioxide needs for each person. This ventilation rate is approximately $5 \mathrm{cfm}$ per person. However, this can be overriden by exhaust air requirements such as toilet or kitchen exhaust 
or by special requirements for medical facilities. As ventilation was reduced, building exhaust was reduced proportionally so that the building was always slightly pressurized, eliminating infiltration.

Window alterations

Three different measures were considered relative to windows. They were (1) internal shading by installing a curtain or blind, (2) installation of dual pane windows, and (3) reduction in window area. Item (1) could be accomplished inexpensively while item (2) requires replacement of all windows and would be considerably more expensive. Item (3) would be considered for buildings having large window areas and would require removal of windows, reducing the opening size and reinstallation of smaller windows or just the installation of opaque material behind a portion of each window. Savings from these measures are primarily reduced heat loss from the building she1l. However, large windows on the south wall can reduce heating energy requirements by operating as a passive solar collector.

Economizer cycle

An enthalpy-temperature economizer is added to lower energy use for cooling. This cycle uses outside air for cooling when the ambient air is more suitable for use than the return air. This cycle is most effective when the building has core areas requiring cooling in winter as well as evenings when the ambient temperature is low. It should be noted that the prior application of thermostat setback during evening hours considerably reduces the effectiveness of an economizer. 
Reset controls

For the base cases all air circulating HVAC systems employed a fixed cold deck ${ }^{*}$ temperature and a hot deck ${ }^{\dagger}$ temperature that was reset based on outside temperature. Zone demand reset control of the temperature of the supply air is considered only for the dual duct and multizone systems. These controls adjust hot air temperature to satisfy the zone having the largest current heating demand and cold air temperature is reset to satisfy the zone having the largest current cooling demand. This measure is quite effective under conditions of "light" load. Otherwise these temperatures must be set and maintained to meet seasonal peak demands which occur infrequently resulting in higher energy use than necessary.

Improvement in equipment efficiencies

The ASHRAE 90-75 standard sets minimum performance levels for chlllers available in 1980 . The standard requires approximately a $10 \%$ improvement in the coefficient of performance over the 1977 standard. Consequently when chillers are replaced in existing buildings, $10 \%$ or more cooling energy savings should be realized. A chiller may also be replaced by one of smaller capacity, both due to improved performance and to other energy conservation measures which have reduced the peak cooling load.

\footnotetext{
${ }^{*}$ Air temperature leaving the cooling coil.

${ }^{\dagger}$ Air temperature leaving the heating coil.
} 


\section{BUILDING DESCRIPTIONS}

Wa11 and roof construction

All pre-embargo building types have the same wall and roof construction as do all post-embargo buildings. Construction details are given in Table 2. A comparison of each building envelope to the ASHRAE 90-75 standard for each building located in Kansas City is given in Table 3.

\section{$\underline{\text { Hospital }}$}

The hospital selected is a four-story $250 \times 100 \mathrm{ft}$ rectangular building with a flat roof and a height of $52 \mathrm{ft}$. The longer side of the building is oriented facing south. The hospital is assumed to have 180 beds with patient rooms, lounges, waiting rooms, nurses stations, etc., occupying $50 \%$ of the floor space, the remainder being treatment rooms, kitchen, laundry, offices, cafeteria, and other areas of higher internal loads and ventilation requirements. Figure 1 shows a plan view of the 5 zones of the building. Patient rooms, etc. are located around the periphery (zones 1-4) with treatment rooms, etc. located in the core (zone 5).

Thermostat setback can be applied only to the core (zone 5) of the hospital since the perimeter areas are normally occupied at all times.

Ventilation rates are based on $\triangle$ SHRAE $62-73^{5}$ and are set at 2.0 air changes per hour in the periphrey rooms (zones 1-4) and at 4.5 air changes per hour in the core (zone 5). 
Table 2. Building construction details

\begin{tabular}{|c|c|c|}
\hline Building type & Pre-embargo & Post-embargo \\
\hline \multicolumn{3}{|c|}{ Wa11 construction } \\
\hline A11 & $\begin{array}{l}\text { 4" face brick } \\
\text { 1" air space } \\
\text { 8" lightweight concrete } \\
\text { block }\end{array}$ & $\begin{array}{l}\text { 4" face brick } \\
\text { 1" air space } \\
\text { 8" lightweight concrete } \\
\text { block } \\
\text { 1" insulation } \\
3 / 8 \text { " gypsum board }\end{array}$ \\
\hline \multicolumn{3}{|c|}{ Roof construction } \\
\hline$A 11$ & $\begin{array}{l}\text { Built up roofing } \\
1 / 2^{\prime \prime} \text { stone } \\
3 / 8^{\prime \prime} \text { felt } \\
1^{\prime \prime} \text { insulation } \\
\text { Metal deck } \\
\text { Acoustic tile }\end{array}$ & $\begin{array}{l}\text { Built up roofing } \\
1 / 2 \text { " stone } \\
3 / 8^{\prime \prime} \text { felt } \\
\text { 3" insulation } \\
\text { Metal deck } \\
\text { Acoustic tile }\end{array}$ \\
\hline \multicolumn{3}{|c|}{ Window construction } \\
\hline All & $\begin{array}{l}\text { Single pane } \\
\text { No shading } \\
1 / 8^{\prime \prime} \text { glass }\end{array}$ & $\begin{array}{l}\text { Single pane } \\
\text { No shading } \\
1 / 8^{\prime \prime} \text { glass }\end{array}$ \\
\hline \multicolumn{3}{|c|}{ Window area (percentage of total wall area) } \\
\hline Hoopital & $25 \%$ (each exposure) & $20 \%$ (each exposure) \\
\hline Office & $30 \%$ (each exposure) & $22.5 \%$ (each exposure) \\
\hline Educationa1 & $\begin{array}{l}50 \% \text { (classrooms, offices } \\
\text { \& cafeteria) } \\
0 \% \text { (kitchen \& restrooms) }\end{array}$ & $\begin{array}{l}38 \% \text { (classrooms, offices } \\
\text { \& cafeteria) } \\
0 \% \text { (kitchen \& restrooms) }\end{array}$ \\
\hline Retail-wholesale & $\begin{aligned} & 40 \% \text { (south wall) } \\
& 0 \% \text { (other walls) }\end{aligned}$ & $\begin{aligned} 40 \% & \text { (south wa11) } \\
0 \% & \text { (other wa11s) }\end{aligned}$ \\
\hline
\end{tabular}

Exhaust air is maintained slightly below the ventilation rate so that the building is pressurized, minimizing infiltration.

The building is occupied by a maximum of 680 people during working/ visiting hours, decreasing gradually to a third shift occupancy of 250 people. The lighting level is 1.75 watts $/ \mathrm{ft}^{2}$ and 2.5 watts $/ \mathrm{ft}^{2}$ in 


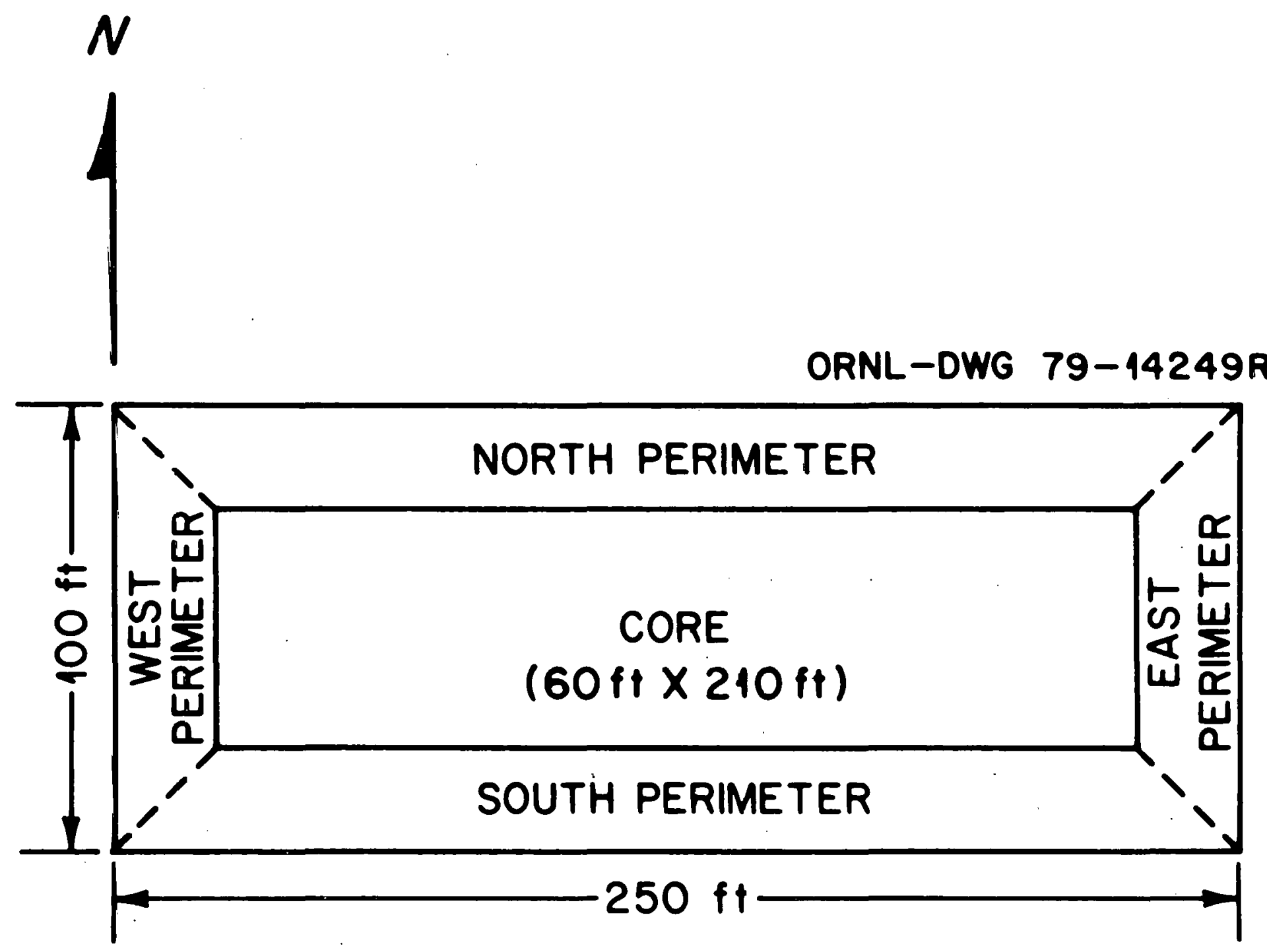

Fig. 1. Plan view of hospital. 
Table 3. Comparison of construction to ASHRAE 90-75 standard

\begin{tabular}{lccc}
\hline & Pre-embargo & Post-embargo & ASHRAE 90-75 \\
\hline $\begin{array}{l}\text { Roof Uo }{ }^{2} \\
\text { All buildings }\end{array}$ & & & \\
& & & .086 \\
Wall Uo & & & \\
Hospital & & & .36 \\
Office & .319 & .232 & .30 \\
Educational & .336 & .30 & .30 \\
Retail-wholesale & .457 & .29 & .30 \\
& .287 & .27 & \\
Wall OTTV & & & 33.5 \\
Hospital & & 30.6 & 33.5 \\
Office & 38.9 & 33.5 & 33.5 \\
Educational & 44.7 & 29.6 & \\
Retail-wholesale & 51.8 & 19.0 & \\
\hline
\end{tabular}

lstandard applied to Kansas City.

${ }^{2}$ Overall average thermal transmittance of the gross area

$\left(\mathrm{Btu} / \mathrm{hr}-\mathrm{ft}^{2}{ }^{\circ} \mathrm{F}\right)$. Includes roof, skylights, walls, windows, etc.

Used for heating calculations.

${ }^{3}$ Ovierall thermal transfer value (Btu/hr-ft ${ }^{2}$ ). Includes walls

and windows. Used for cooling calculations.

the periphery and core zones respectively, while corresponding equipment loads are 0.5 and 2.5 watts $/ \mathrm{ft}^{2}$. During late evening and early morning hours, lighting and internal loads are reduced to $10 \%$ of maximum in the core, while in the periphery zones, the reduction is to $40 \%$.

The HVAC system includes a fossil fired steam boiler having a full-load efficiency of $75 \%$ and a centrifugal electric chiller. For the pre-embargo building, the chiller COP is 3.95 at standard rating conditions per ASHRAE 90-75. The yearly average COP for this system is approximately 2.0. For the post-embargo building, COP values are 4.33 and 2.2 respectivley. The yearly average $\mathrm{COP}$ is the ratio of yearly cooling load to the electrical energy use of the chiller, water pumps, cooling 
tower fans, and controls. The duct system to the core of the preembargo hospital is a single zone system with face and bypass dampers which supplies a fixed amount of outside air while the perimeter system is four-pipe fan coil units. A variable volume system was considered for the core of the post-embargo hospital, but was not compatible with the high ventilation requirements. Consequently, a single zone system incorporating an enthalpy temperature type economizer was selected. System control is by linear proportional thermostats set for maximum cooling at $78^{\circ} \mathrm{F}$ and maximum heating at $72^{\circ} \mathrm{F}$.

The monthly heating and cooling energy consumption for both the

pre- and post-embargo hospital is shown in Fig. $2 .^{*}$ (discussed later in Sect. 4)

Office

The office building is a three story structure, $150 \mathrm{ft} \times 90 \mathrm{ft}$, with a height of $36 \mathrm{ft}$ and a total of 40,500 square feet. The building consists of offices, conference rooms, and restrooms located around the perimeter and an open area in the corc of each floor. 'l'he same basic building is used for both the pre- and post-embargo studies, with the differences being primarily in the building envelope. The post-embargo building walls and roof conform to the recommended overall thermal transfer values in ASHRAE 90-75. Both buildings are divided into 5 zones for purposes of heating and air conditioning. The five zones of the building and the building orientation are shown in a plan view in Fig. 3 .

\footnotetext{
${ }^{\star}$ Electricity at $11,500 \mathrm{Btu} / \mathrm{kWh}$.
} 


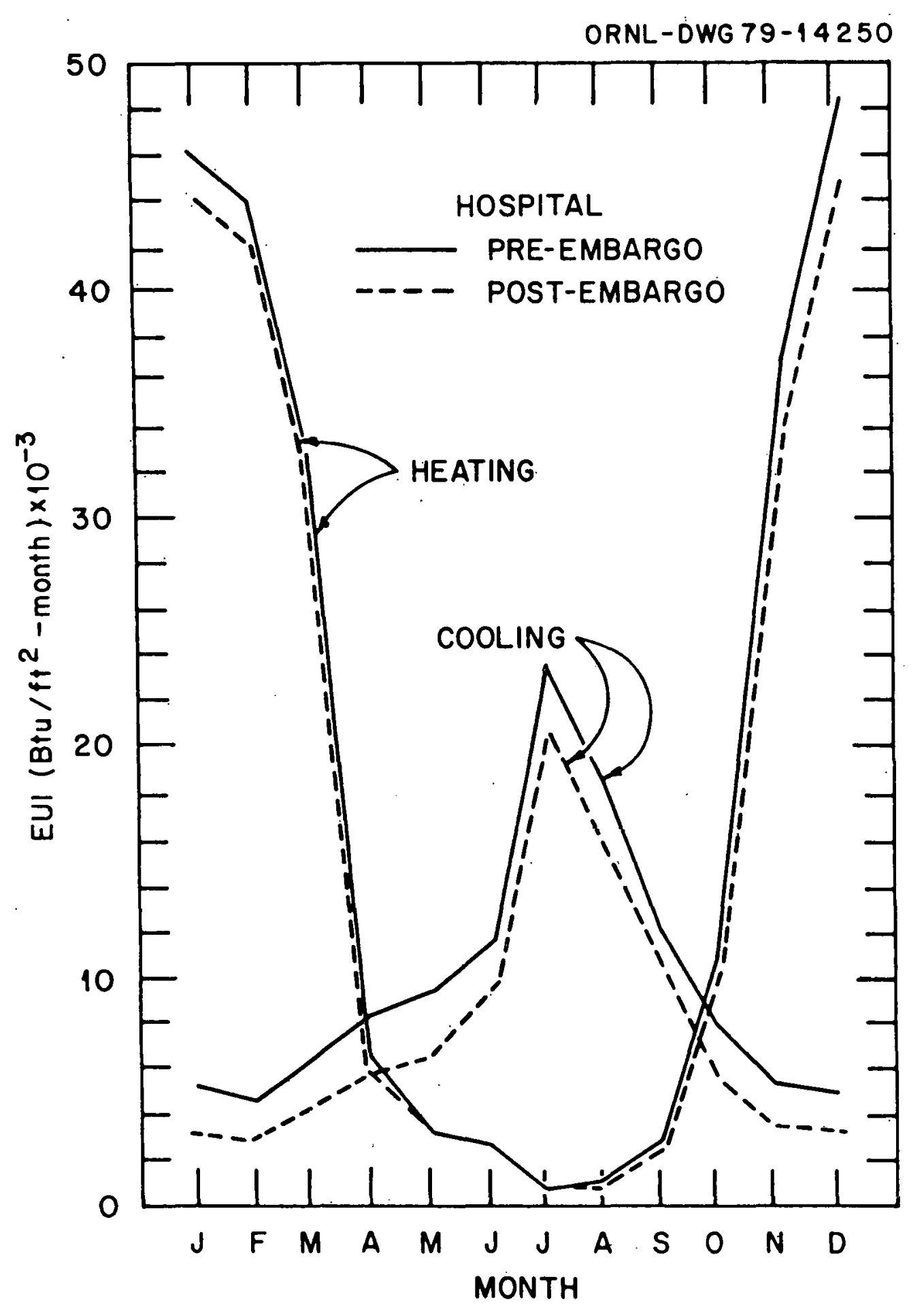

Fig. 2. Monthly energy consumption - base case hospital. 


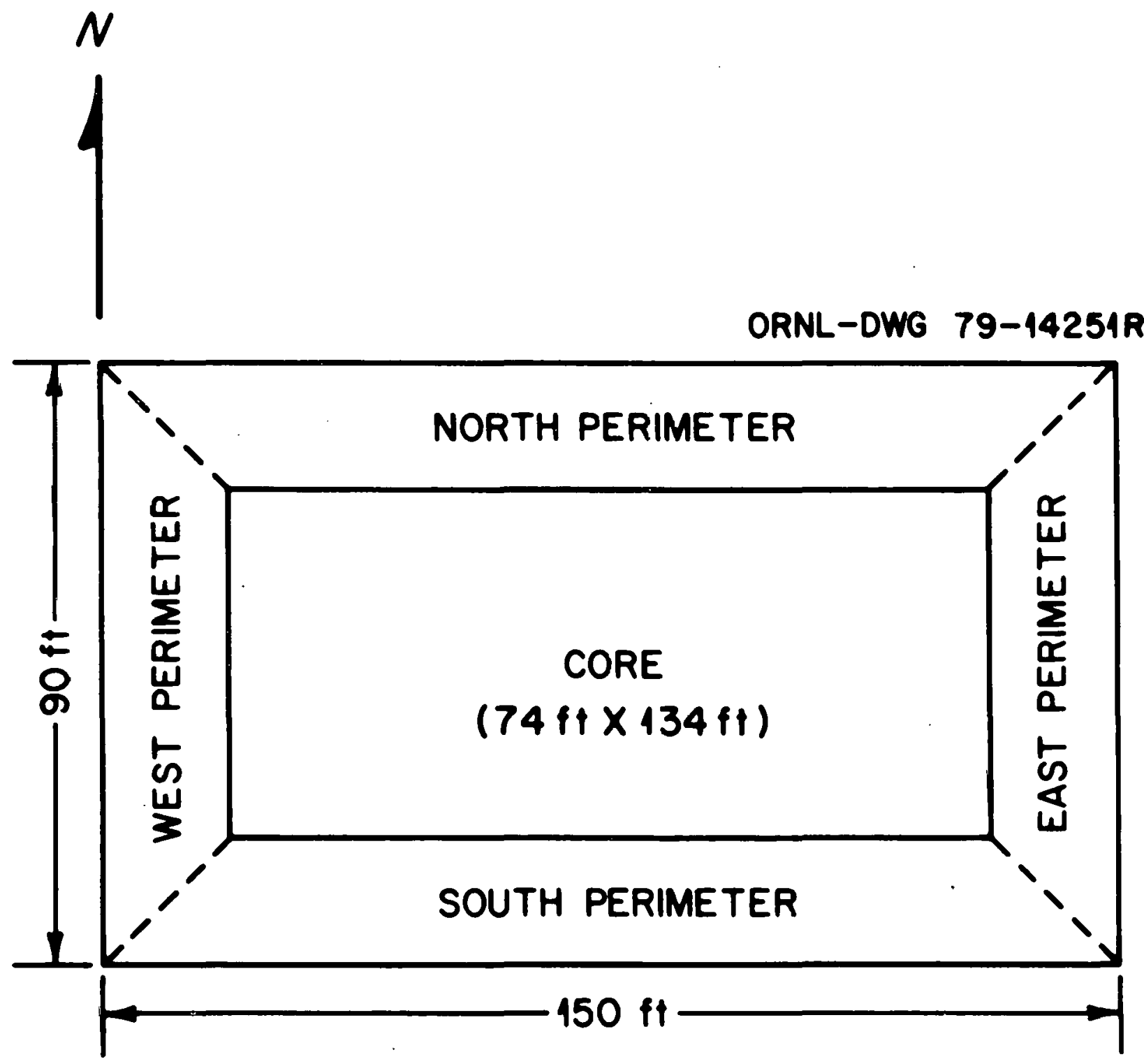

Fig. 3. Plan view of office. 
The building is occupied by 258 people who work from 8:00 to 5:00 Monday through Friday. The lighting level is set at 3 watts $/ \mathrm{ft}^{2}$ and the heat generated by equipment located in the zones is 0.75 watts $/ \mathrm{ft}^{2}$. The lights and equipment are considered to operate at $98 \%$ of peak values from 8:00 to 5:00 weekdays and at $3 \%$ all other times.

Ventilation and exhaust requirements for the pre-embargo building are based on $\mathrm{ASHRAE}^{5}$ recommendations. The ventilation rate is $20 \mathrm{cfm} /$ person which is the average of the recommended range in ASHRAE standard 62-73. The quantity of air exhausted from the building is maintained at a level slightly below the ventilation rate to slightly pressurize the building and reduce infiltration. The exhaust consists of $2 \mathrm{cfm} / \mathrm{ft}^{2}$ from the restrooms, $1 \mathrm{cfm} / \mathrm{ft}^{2}$ from conference rooms, and the remainder drawn from the core area.

The ventilation rate for the post-embargo office building is slightly higher than the pre-embargo building. These values are also taken from ASHRAE $62-73^{5}$ but are the recommended ventilation rates for specific areas as noted below.

- Private office space - $25 \mathrm{cfm} /$ person

- Open office area - $15 \mathrm{cfm} /$ person

- Conference room - $40 \mathrm{cfm} /$ person

- Restroom - $25 \mathrm{cfm} /$ person

This increases ventilation airflow approximately $15 \%$ over the preembargo building. The exhaust requirements remain unchanged for the restrooms and conference rooms. The total building exhaust is again maintained at a level slightly below the ventilation rate to reduce infiltration. 
The pre-embargo office building is heated and air-conditioned by a multizone system which supplies a fixed amount of outside air. The system hot deck temperature resets on outside air timperature, and the cold deck temperature is fixed at $55^{\circ} \mathrm{F}$. The reset schedule consists of varying the hot deck temperature from $120^{\circ} \mathrm{F}$ to $90^{\circ} \mathrm{F}$ as the outside air temperature increases from $0^{\circ} \mathrm{F}$ to $60^{\circ} \mathrm{F}$. The hot deck and cold deck air streams are mixed proportionately to deliver the required air temperature to each zone. A linear proportional thermostat controls each zone with maximum cooling at $76^{\circ} \mathrm{F}$ and maximum heating at $72^{\circ} \mathrm{F}$. The system is served by a fossil fired boiler with a full load efficiency of $75 \%$ and an electric hermetic reciprocating water chiller having a rated COP of 3.25 .

The HVAC system in the post-embargo office building includes four constant volume systems (one serving each of the perimeter zones), and a variable air volume system for the core. All the systems have enthalpy temperature economizers and linear proportional thermostats set for maximum cooling at $76^{\circ} \mathrm{F}$ and maximum heating at $72^{\circ} \mathrm{F}$. The systems are served by a fossil fired boiler with an efficiency of $75 \%$ and an electric hermetic reciprocating water chiller with a rated COP of 3.58 per ASHRAE $90-75$.

The monthly heating and cooling energy consumption of both pre- and post-embargo office buildings is shown in Fig. 4 (discussed in Sect. 4 ). 


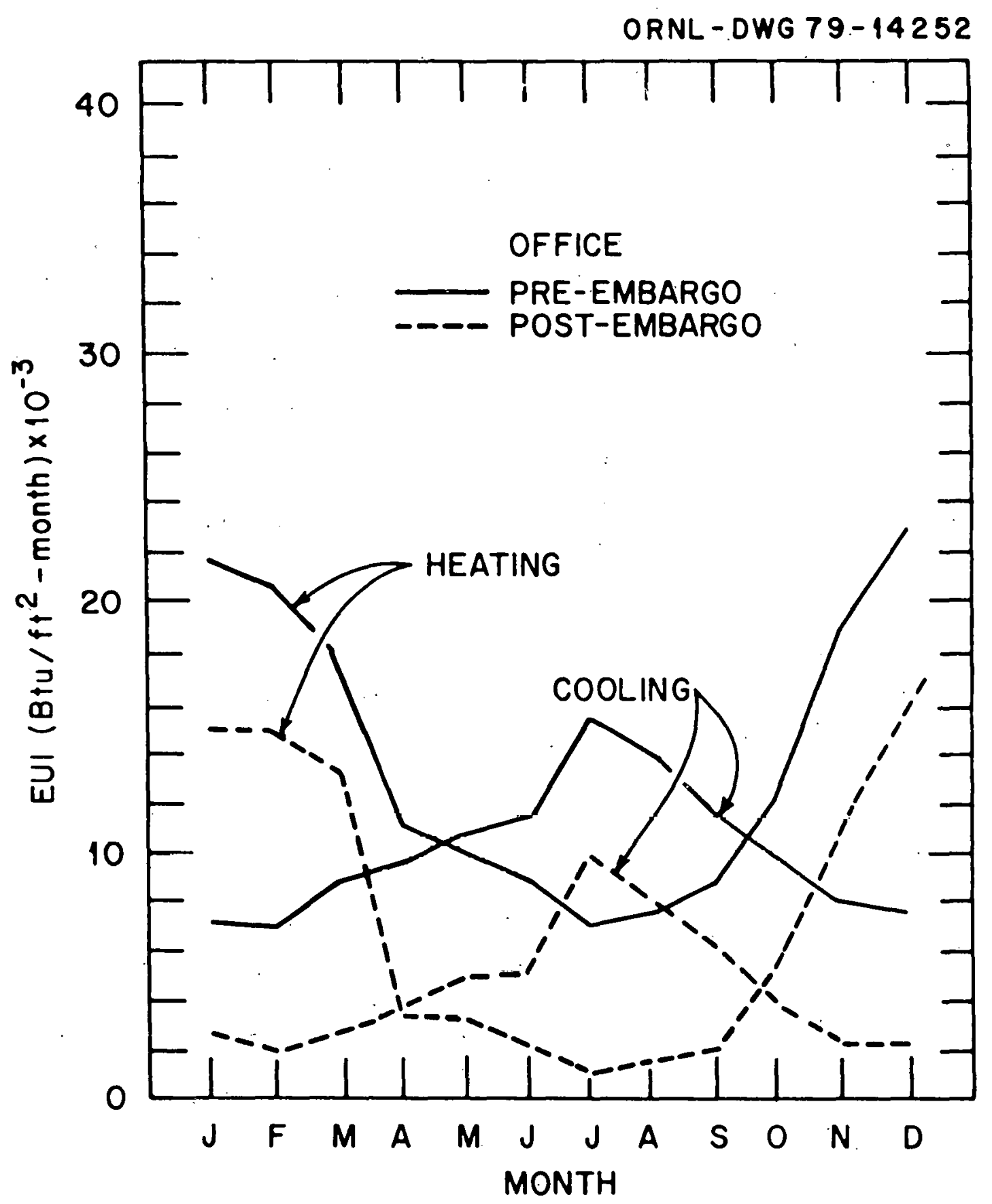

Fig. 4. Monthly energy consumption - base case office. 
$\underline{\text { Educational }}$

The educational facility is an elementary school with a floor area of 28,900 square feet containing 18 classrooms, office, cafeteria, kitchen, and restrooms. The building is a one story structure, 445 feet 1ong, 65 feet wide, and 12 feet high. It is oriented with the long sides facing north and south, as shown in Fig. 5. The classrooms are located along the north and south walls and are connected to a common corridor. The office and restrooms are located on the east end of the building, and the kitchen and cafeteria on the west end. For the purposes of modeling, the building is divided into six zones: north and south classrooms, office, restrooms, cafeteria, and kitchen.

The facility is operated 9 months (January through May and September through December) per year and completely shut down the remaining 3 months. As with the office building, the primary differences between pre- and post-embargo educational buildings are changes in the building envelope.

The ventilation requirements for the building are based on ASHRAE 62-73 and the applications volume of the ASHRAE Guide and Data Book. ${ }^{6}$ The values selected were:

- Classrooms - $18 \mathrm{cfm} /$ person

- Office - $15 \mathrm{cfm} /$ person

- Restrooms $-2 \mathrm{cfm} / \mathrm{ft}^{2}$

- Cafeteria - $18 \mathrm{cfm} /$ person

- Kitchen $-4 \mathrm{cfm} / \mathrm{ft}^{2}$ 
4

ORNL-DWG 79-14253

\begin{tabular}{|l|l|l|l|l|}
\hline & & & & \\
\hline
\end{tabular}

Fig. 5. Pian view of educational building. 
Ventilation rates for the classrooms and the cafeteria are based on the values required to dilute objectionable body odors to an acceptable threshold, and depend on the cubic feet of air space per person. The quantity of air exhausted from the building was maintained at a level slightly below the ventilation requirement to slightly pressurize the building and reduce infiltration.

The lighting level was 3 watts $/ \mathrm{ft}^{2}$ in all the areas. The equipment heat load was confined mostly to the kitchen area and consisted of $16,150 \mathrm{Btu} / \mathrm{hr}$ sensible and $18,750 \mathrm{Btu} / \mathrm{hr}$ latent heat. The occupancy of the building is 630 students and teachers, 17 cafeteria workers, and 7 administrative personnel. The classroom people density is $25 \mathrm{ft}^{2} /$ person, which is greater than the $20 \mathrm{ft}^{2} /$ person recommended by ASHRAE 62-73. The classroom and office schedules for occupants, lights, and equipment include (percent full load): $0 \%$ from 12 p.m. to 8 a.m., 100\% from 8 a.m. to 12 a.m., $50 \%$ from 12 a.m. to 1 p.m., 100\% from 1 p.m. to 3 p.m., $10 \%$ from $3 \mathrm{p} . \mathrm{m}$. to $6 \mathrm{p} \cdot \mathrm{m}$. , and $0 \%$ from $6 \mathrm{p} . \mathrm{m}$. to $12 \mathrm{p} . \mathrm{m}$. on weekdays. On the weekends the percent of full load is $0 \%$ for 24 hours per day. The kitchen schedule for lights and occupants is $100 \%$ from 8 a.m. to 3 p.m. weekdays and $0 \%$ all other times on weekdays. The equipment schedule for the kitchen is $100 \%$ from 8 a.m. to 12 a.m., $25 \%$ from 12 a.m. to 3 p.m. weekdays and $0 \%$ all other t1mes. The cafeteria light and equipment schedule is $100 \%$ from 8 a.m. to 3 p.m. weekdays and $0.0 \%$ all other times, while the occupancy schedule is $2 \%$ from $8 \mathrm{a} \cdot \mathrm{m}$. tn $12 \mathrm{p} \cdot \mathrm{m}$. and 1 p.m. to 3 p.m., $100 \%$ from 12 a.m. to 1 p.m. on weekdays and $0 \%$ at all other times. 
The systems selected for the pre-embargo educational building are a multizone system for the classrooms and office, a single-zone system with face and bypass dampers for the cafeteria, and a heating and ventilating system for the kitchen. The single and multizone systems are equipped with enthalpy/temperature economizers. The multizone system hot and cold deck temperatures were fixed at $120^{\circ} \mathrm{F}$ and $52^{\circ} \mathrm{F}$ respectively. The classrooms, cafeteria, and office have proportional thermostats with high and low limits of $76^{\circ} \mathrm{F}$ and $72^{\circ} \mathrm{F}$, while the kitchen proportional thermostat has limits of $75^{\circ} \mathrm{F}$ to $68^{\circ} \mathrm{F}$. The building temperature is allowed to fall to $60^{\circ} \mathrm{F}$ by shutting the systems off at night and on the weekends. This is accomplished by changing the linear proportional thermostats to off-on operation from $6 \mathrm{p} . \mathrm{m}$. to $6 \mathrm{a} \cdot \mathrm{m}$. on weekdays and all weekend. The systems are served by a fossil fired boiler with an efficiency of $75 \%$ and a reciprocating water chiller with a rated COP of 3.25 .

Tho post-pmhargo HVAC systems used were the same as the pre-embargo building for the cafeteria (single-zone) and the kitchen (heated and ventilated), however the system serving the classrooms was changed from a multizone to a dual duct. The dual duct system was equipped with an enthalpy/temperature economizer and had fixed hot and cold deck discharge temperatures of $120^{\circ} \mathrm{F}$ and $52^{\circ} \mathrm{F}$ respectively. The thermostats and the annual system operating characteristics for these systems were the same as the pre-embargo building. The reciprocating water chiller used in this building has a rated COP of 3.58 as required in ASHRAE 90-75. The monthly energy consumption for heating and cooling for both the preand post-embargo educational building is given in Fig. 6 (see Sect. 4). 


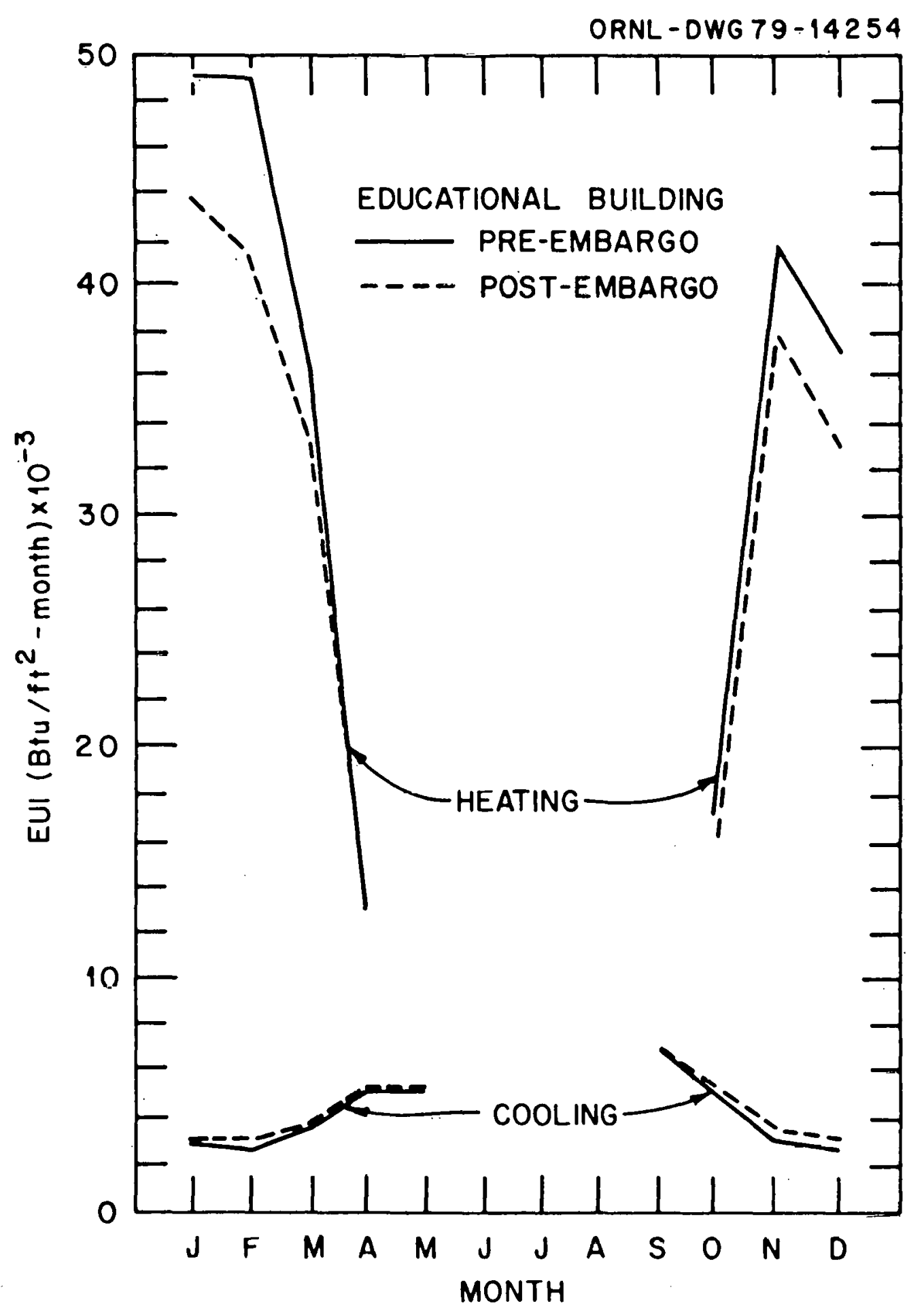

Fig. 6. Monthly energy consumption - base case educational building. 
$\underline{\text { Retail-wholesale }}$

The retail-wholesale establishment is a single story structure $10 \mathrm{ft}$ high and consists of a department store, food store, and cafeteria. The building front faces south with the department store located between the food store and the cafeteria (see Fig. 7). The floor areas of the department store, food store, and cafeteria are 40,500 $\mathrm{ft}^{2}, 14,700 \mathrm{ft}^{2}$, and $10,100 \mathrm{ft}^{2}$ respectively. The complex is analyzed for both pre- and post-embargo designs. The major difference between the structures for the two buildings is that the post-embargo building conforms to the overall thermal transfer coefficient recommended by ASHRAE 90-75.

The ventilation rates were selected from ASHRAE Standard 62-73. The food store sales areas required $15 \mathrm{cfm} /$ person, while the storage and meat processing areas required $5 \mathrm{cfm} /$ person. The sales and storage areas of the department store required $15 \mathrm{cfm} /$ person and $10 \mathrm{cfm} /$ person respectively. The cafeteria ventilation was divided into storage area, kitchen, and seating area. The resulting values employod were $10 \mathrm{rfm} /$ person, $4.0 \mathrm{cfm} / \mathrm{ft}^{2}$, and $15 \mathrm{cfm} /$ person for the storage area, kitchen, and seating areas, respectively.

The maximum number of occupants for each store was based on the recommended occupancy densities from ASHRAE Standard 62-73. These maximum numbers were: 372 for the food store, 911 for the department store and 530 for the cafeteria. Hours of operation for each store were as follows: food store - 9 a.m.-12 midnight, 6 days per week; cafeteria - 8 a.m.-10 p.m., 7 days per week; department store - 10 a.m.9 p.m., 6 days per week. 


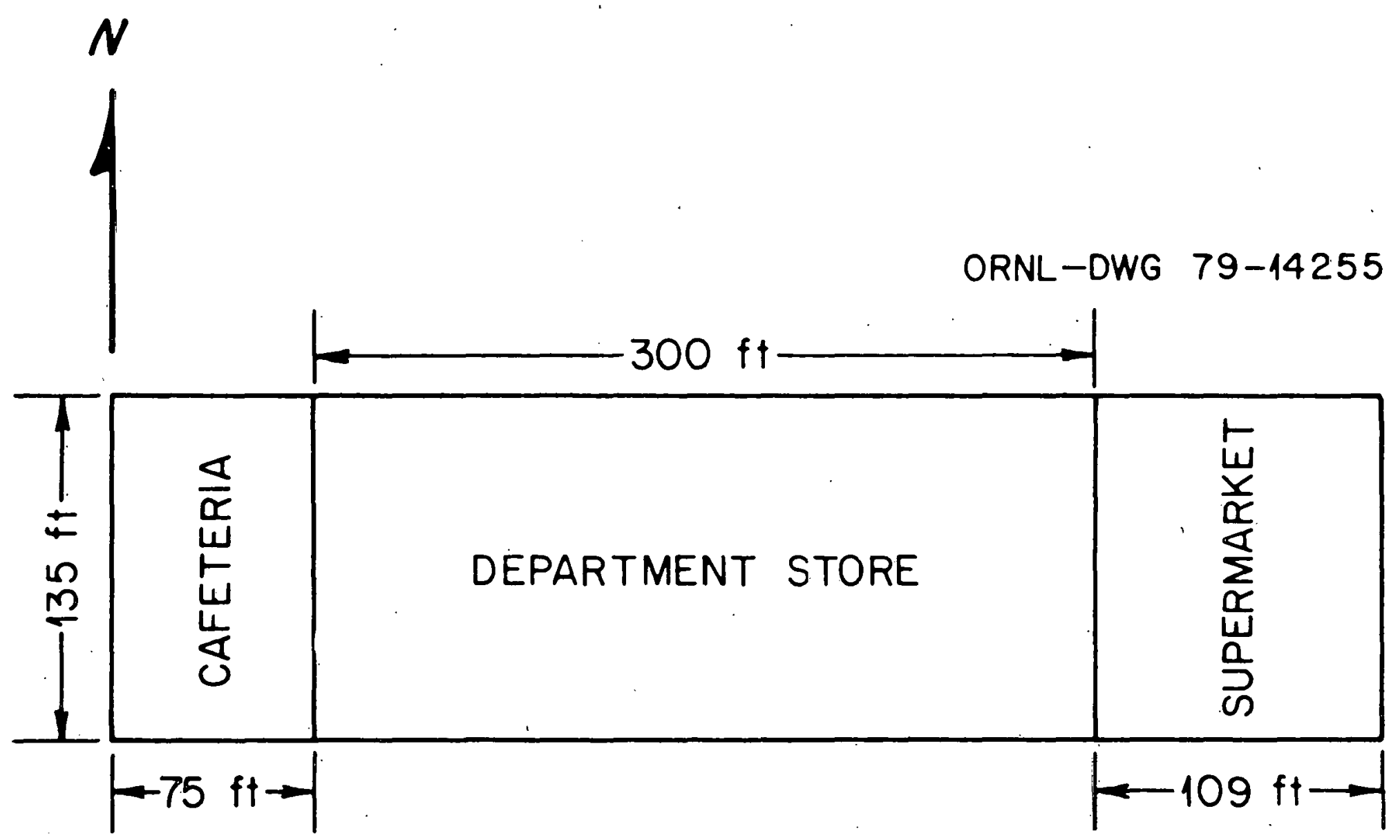

Fig. 7. Plan view of retail building. 
The internal heat loads for the food store consisted of a lighting level of 7 watts/ft ${ }^{2}$ and a cooling effect of 8.5 tons from the meat and dairy display cases. The department store lighting load was also 7 watts $/ \mathrm{ft}^{2}$. The heat load of the cooking equipment located in the kitchen of the cafeteria was $89 \mathrm{MBtu} / \mathrm{hr}$ and the lighting level was 3 watts/ft ${ }^{2}$.

The HVAC systems in the pre-embargo case included individual constant volume reheat systems for each store. The systems used for the post-embargo case were the same. The systems were served by a hermetic centrifugal water chiller with a rated COP of 3.95 for the pre-embargo building and 4.33 for the post-embargo building, and a fossil-fired boiler with an efficiency of $75 \%$ for both buildings. The monthly heating and cooling energy consumption of both pre- and post-embargo buildings is given in Fig. 8 .

\section{RESULTS}

Energy use is presented as an energy use index (EUI) which is energy consumed per square foot of floorspace per year (Btu/ft $\left.{ }^{2}-\mathrm{yr}\right)$. Electricity is converted at the rate of 11,500 . Btu/Kwh to account for losses in generation, transmission, and distribution allowing all energy terms to be presented as primary energy.

Results are presented in bar charts showing energy use for each end use: space heating, space cooling, lighting, internal loads, and fans and controls. It should be noted that moving to the right, each conservation measure as indicated is added to all those to the left to show a cumulative effect. The measures considered first were those with the 


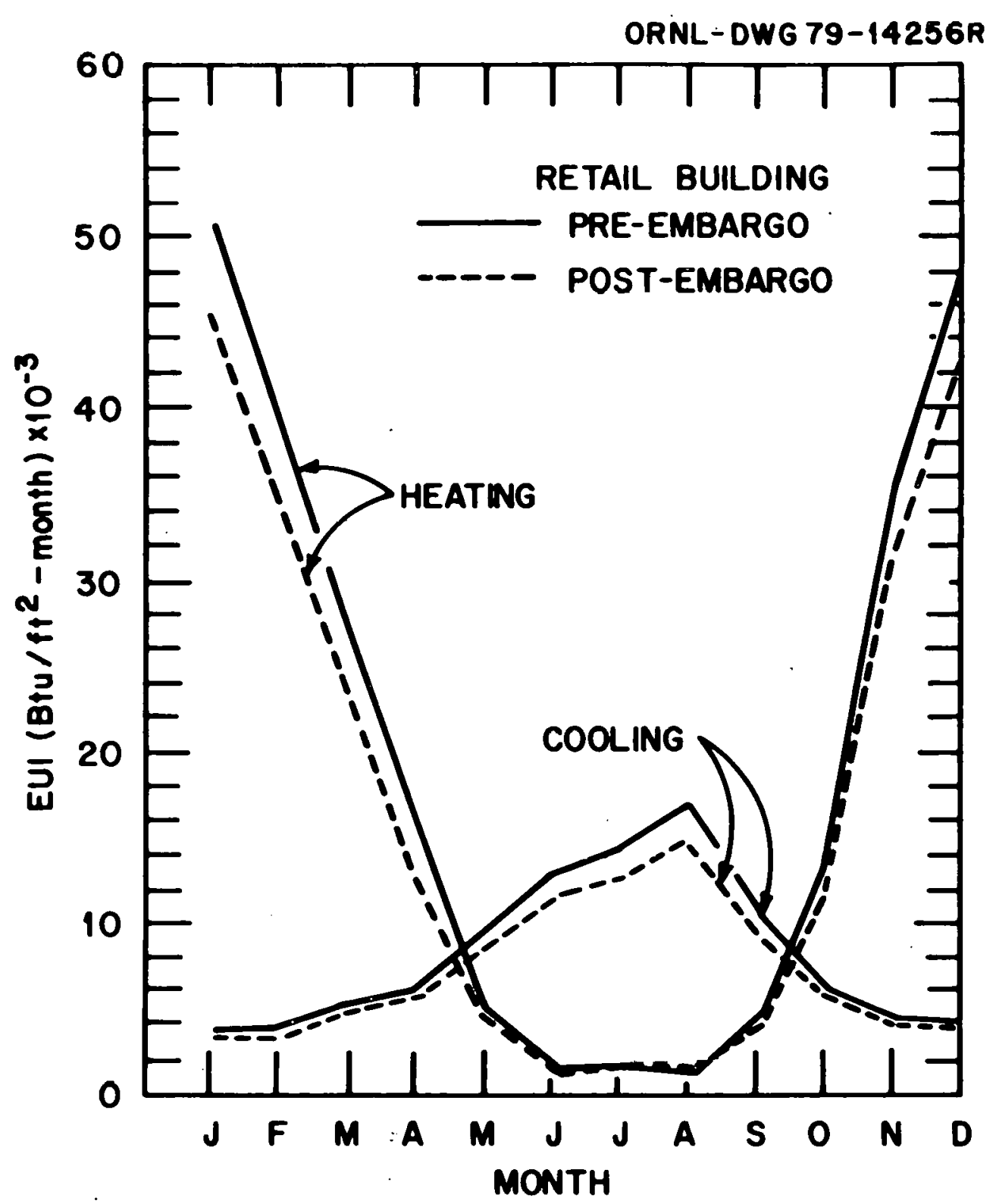

Fig. 8. Monthly energy use - base case retail building. 
shortest payout periods.* Some of the various energy conservation options would project different percent savings if taken in a different order. However; reducing windows, lighting and ventilation will have virtually the same percentage energy reduction relative to the base case no matter when they occur.

$\underline{\text { Results-hospital }}$

The energy use index for the base case pre-embargo hospital was $608 \mathrm{MBtu} / \mathrm{ft}^{2}-\mathrm{yr}$ which is about $8 \%$ higher than the national average value as estimated by Jackson. ${ }^{2}$ Figure 9 shows energy savings for various conservation measures. The first energy conservation measure considered was setting the thermostat limits to $55^{\circ}$ and $90^{\circ}$ in the core zone in the evenings and on weekends which produced a $20 \%$ energy savings, virtually all in heating. A $15 \%$ reduction in outside ventilation air to the core produced a $7 \%$ additional energy savings again, primarily heating energy. Such a reduction could be carried out selectively by reducing outside air during evening hours or the selection of areas within the core (offices, etc.) where less than 4.5 air changes per hour is acceptable. The next measure was a $20 \%$ reduction in lighting throughout the hospital resulting from the selective removal of lamps and/or replacement of incandescent lamps with more efficient fluorescent ones. This produced an additional $3 \%$ energy savings with the reduction in lighting and cooling being larger than the additional heating required.

\footnotetext{
${ }^{*}$ Only simple payouts based on 1978 dollars were considered.
} 


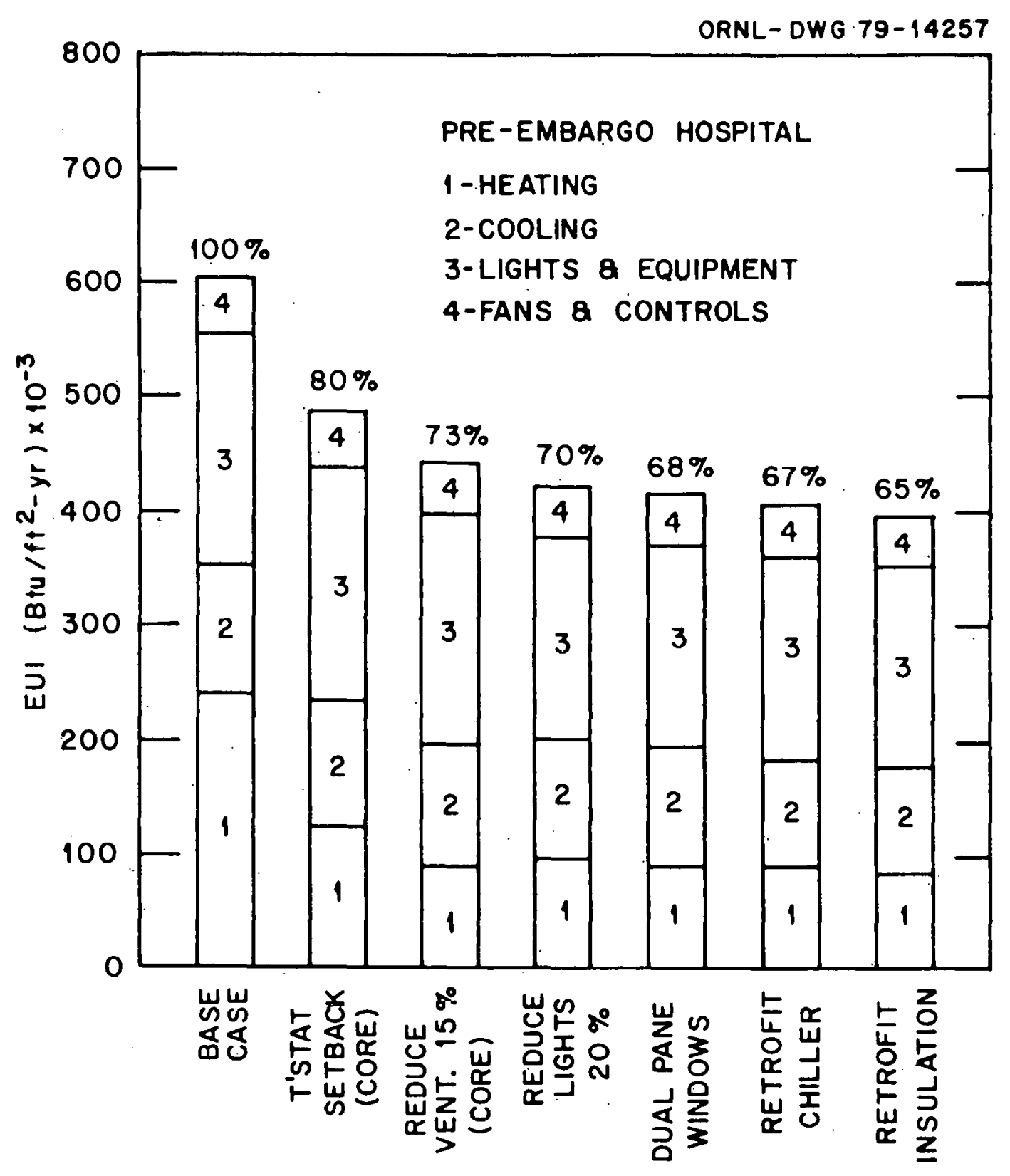

Fig. 9. Results of conservation measures - pre-embargo hospital. 
Replacement of all windows in the building with dual pane windows through retrofit produces a $2 \%$ additional saving, primarily in heating energy. Replacement of a typical pre-embargo chiller with one having a COP in accordance with ASHRAE 90-75 produces a $10 \%$ decrease in cooling energy required and corresponds to an overall energy savings of $1 \%$.

A relatively expensive conservation measure is the addition of insulation to the wall and roof of a building through retrofit. The addition of 1 " of fiberglass to the building walls and 2 " of fiberglass to the roof (making a total of $3^{\prime \prime}$ ) produces an additional $2 \%$ energy savings.

It should be noted that all energy conservation measures primarily affect space heating energy use. Cooling is dominated by high internal loads and the high ventilation rate in the core and shows a significant response only to decreased lighting and internal loads and to increased chiller efficiency.

The base case post-embargo hospital has an energy use index of $560 \mathrm{MBtu} / \mathrm{ft}^{2}-\mathrm{yr}$, an $8 \%$ 1mprovement over the pre-embargo hospital. Figure 10 shows the energy savings of various conservation measures. The incorporation of night, weekend, and holiday thermostat setback in the core produced a $21 \%$ savings in energy while a $15 \%$ reduction in core ventilation resulted in an energy savings of $8 \%$. An energy savings of $3 \%$ was projected from a $20 \%$ reduction in lighting while the replacement of all windows with dual panes through retrofit produced an additional 3\% energy savings. As previously stated, all savings are given as a percentage of the base energy use index. 


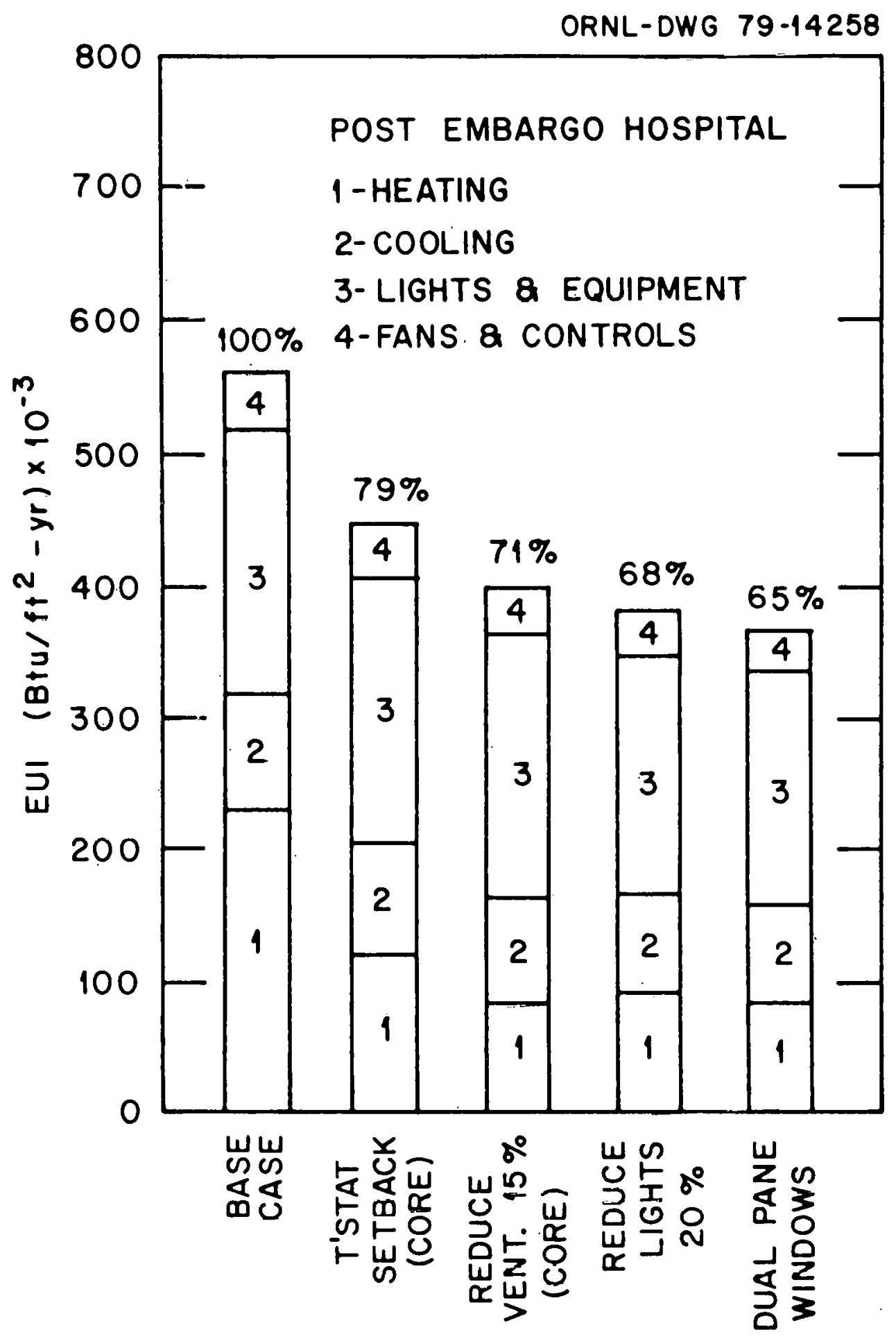

Fig. 10. Results of conservation measures - post-embargo hospital. 


\section{Results-office}

The pre-embargo office building base case EUI was $434 \mathrm{MBtu} / \mathrm{ft}^{2}$-year. The national average as estimated by Jackson ${ }^{2}$ was 351 . The effect on energy use of the conservation measures is shown in Fig. 11. Increased savings over the hospital are primarily due to the fact that the entire building can be shut down at night and on weekends.

Changing the zone thermostat from linear proportional to an on-off type during unoccupied periods $(6 \mathrm{p} . \mathrm{m}$. to $6 \mathrm{a} \cdot \mathrm{m}$.$) on weekdays and all$ weekend resulted in a saving of $37 \%$. The limits on the on-off thermostat were $55^{\circ} \mathrm{F}$ and $85^{\circ} \mathrm{F}$ during unoccupied periods. Reduction of the lights, equipment and ventilation saved $11.6 \%$. The 1ighting and equipment heat generation levels were reduced $33 \%$ and the ventilation was reduced $35 \%$. A savings of $9.1 \%$ was obtained when zone demand reset for the deck temperatures was incorporated. The final modification was reducing the window area to $10 \%$ of the total wall area on each exposure and adding double pane windows. This resulted in a savings of $7.8 \%$.

The post-embargo office building has an energy use index of $276 \mathrm{MBtu} / \mathrm{ft}^{2}$-year, a decrease of $36.5 \%$ over the pre-embargo building. Figure 12 shows the results of various conservation measures for this building. Temperature reset resulted in a $22.5 \%$ savings. The reset consisted of changing the linear proportional thermostat to on-off operation during unoccupied periods as discussed above. This modification was extended to night and weekend shut-off by increasing on-off thermostat high limlt to $105^{\circ} \mathrm{F}$. This resulted in an additional $1 \%$ savings above the reset case, which was due to cooling energy savings. 


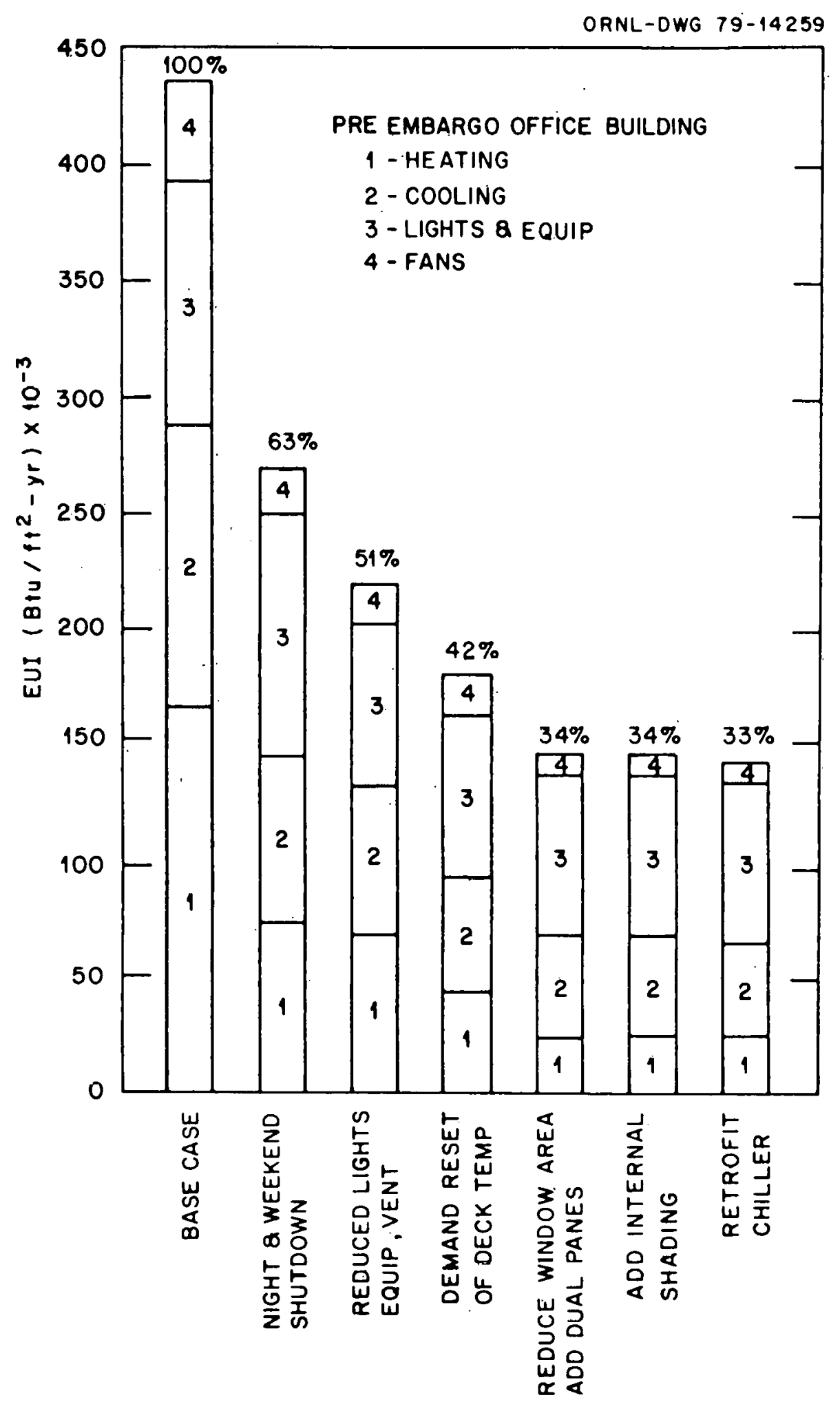

Fig. 11. Results of conservation measures - pre-embargo office building. 


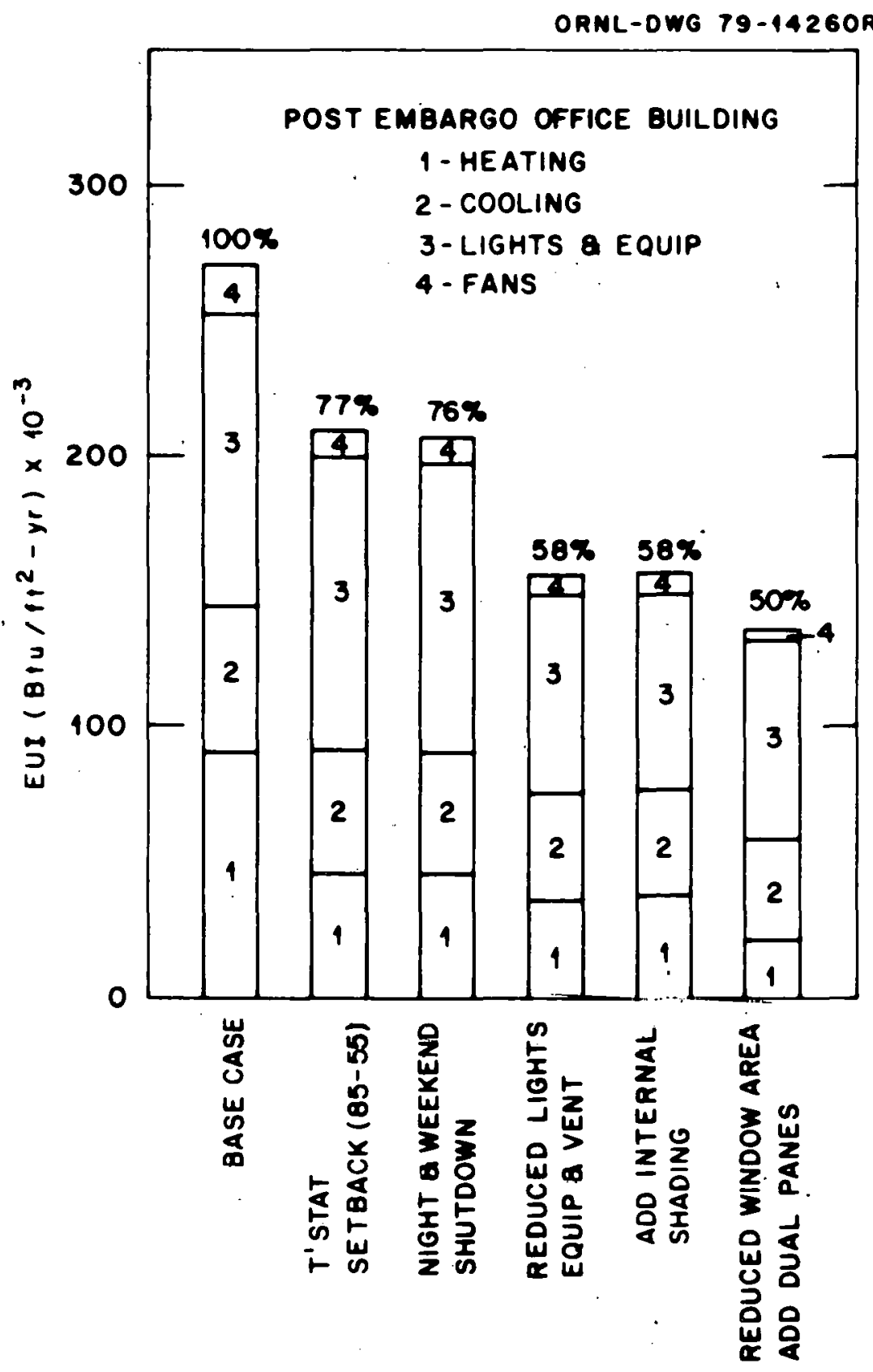

Fig. 12. Results of conservation measures - post-embargo office building. 
Reducing the lighting, equipment, and ventilation levels saved $18.2 \%$. Lighting and equipment levels were reduced $33 \%$, and the ventilation $51 \%$. Adding internal shading to the windows increased energy use by $0.2 \%$, because heating requirements for the south, east, and west zones increased more than the perimeter cooling decreased. Decreasing the window area to $10 \%$ of the total wall area and adding double pane windows saved an additional $7.7 \%$ of the base energy use.

Results-educational facility

The base pre-embargo educational facility had an EUI of $353 \mathrm{MBtu} / \mathrm{ft}^{2}-\mathrm{yr}$ compared to 279 reported by Jackson. ${ }^{2}$ This energy consumption was based on school operation from January through May and September through Decenber. Figure 13 shows the results of varlous energy conservation measures.

The base case, as previously stated, consisted of shutting the system off on weeknights during the winter and letting the space temperature drop to $60^{\circ} \mathrm{F}$ before the system was turned back on. On the weekend the entire system was shutdown and a $40^{\circ} \mathrm{F}$ low limit thermostat was used. The first modifications consisted of shutting the system off on weeknights and allowing the temperature in the building to drop to $40^{\circ} \mathrm{F}$ during the winter. This resulted in an energy savings of $13.4 \%$.

The ventilation rates were reduced to $5 \mathrm{cfn} / \mathrm{person}$ in the classrooms, office, and cafeteria. This level is sufficient to meet oxygen and carbon dioxide requirements. The k1tchen exhaust was reduced from 


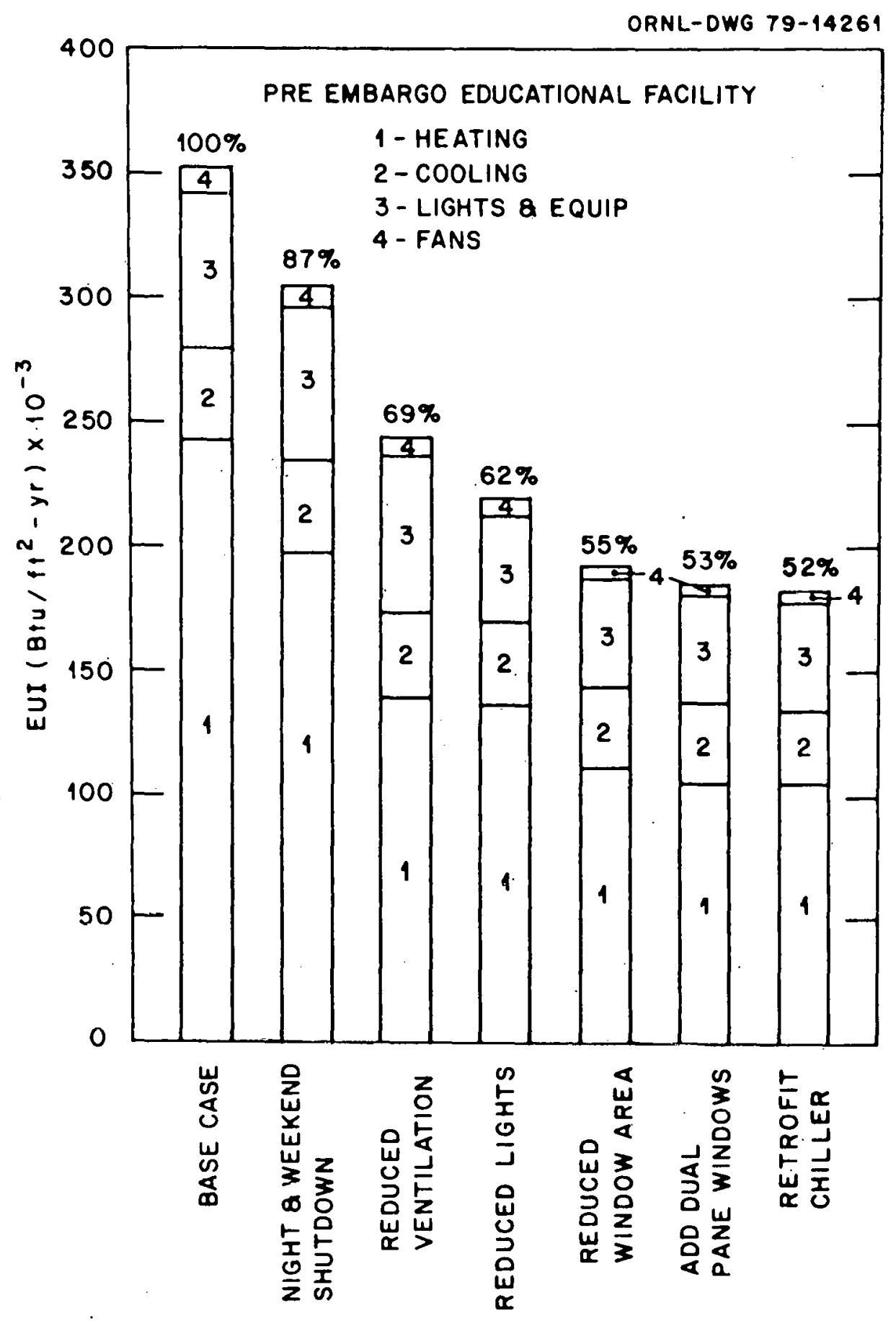

Fig. 13. Results of conservation measures - pre-embargo educational facility. 
$4 \mathrm{cfm} / \mathrm{ft}^{2}$ to $2 \mathrm{cfm} / \mathrm{ft}^{2}$. Reducing the ventilation resulted in an energy savings of $17.5 \%$.

The remaining energy conservation modifications were concerned with the lighting levels and the windows. Reducing the lighting levels from 3 watts/ft ${ }^{2}$ to 2 watts/ft ${ }^{2}$ resulted in a $6.8 \%$ reduction in energy use. The available literature states that a general rule of thumb ${ }^{7}$ for classroom windows is that a minimum area equal to $10 \%$ of the floor area should be maintained. This limitation allowed the classroom window area to be reduced to $21 \%$ of the wall area and the cafeteria and office window area to be reduced to $10 \%$ of the wall area. This reduced the energy consumption by $7.8 \%$. Changing the windows to double pane produced an energy savings of $2.0 \%$.

The post-embargo building had an EUI of $338 \mathrm{MBtu} / \mathrm{ft}^{2}-\mathrm{yr}$, a reduction of $4.2 \%$ over the pre-embargo building. The same energy conservation alternatives analyzed for the pre-embargo building were used in this case. The complete shutdown on weeknights resulted in a savings of 10.8\%. Reducing the ventilation rate saved $21.2 \%$. Lowering the lighting levels cut the energy consumption by $7.0 \%$. The windows were reduced according to the same general rule of thumb as with the preembargo case and a savings of $6.4 \%$ was realized. Replacement of the single pane windows with double panes saved $2 \%$. The base energy use and the effect of the various modifications is presented in Fig. 14. 


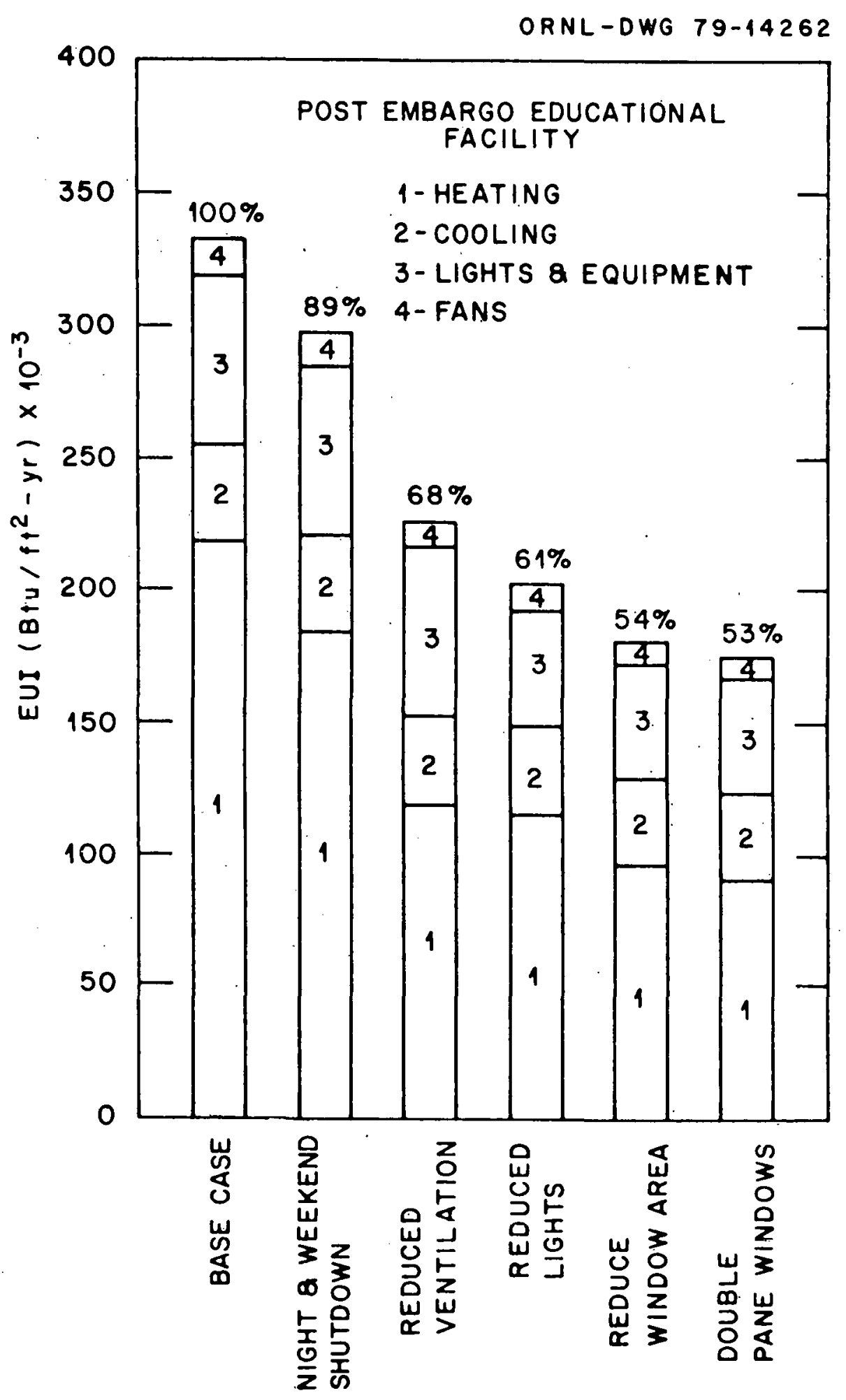

Fig. 14. Results of conservation measures - post-embargo educational facility. 
Results retail-wholesale

The energy use index for the retail-wholesale establishment base case was $698 \mathrm{MBtu} / \mathrm{yr} \mathrm{ft}^{2}$. Jackson ${ }^{2}$ reported average EUI values of retail buildings to be $415 \mathrm{MBtu} / \mathrm{yr}-\mathrm{ft}^{2}$. The inclusion of a grocery store in the retail complex is the primary reason for this rather large difference. Figure 15 shows the results of various energy conservation measures for this building type. The first modification consisted of system sliutoff during unoccupied hours for the cafeteria and the department store. The food store cooling system could not be shutdown because of the possibility of damage to the food. Low limit thermostats set at $40^{\circ} \mathrm{F}$ were used in the stores that were shutdown. This shutdown resulted in an energy savings of approximately $15 \%$. An energy savings of $16 \%$ was realized by reducing the light levels in the various stores, and reducing the ventilation rates saved an additional $11 \%$ of the energy consumption. The lighting levels were reduced from 7 to 3 watts $/ \mathrm{ft}^{2}$ in the grocery and department stores and from 3 to 1.5 watts $/ \mathrm{ft}^{2}$ in the cafeteria. The ventilation rate was reduced by $48 \%$.

The final modifications were associated with the windows. First replacing single pane glass with double pane glass reduced the energy consumption by $1 \%$. The windows were completely removed from the buildings (replaced by walls) and $.64 \%$ of the base energy consumption was saved. Dual pane windows are superior to the replacement of all windows by a wall because of solar heating on the south facing exposure. The same modifications were applied to the post-embargo building that were used with the pre-embargo building and the results are shown in Fig. 16. The energy use index for the base case was $610 \mathrm{MBtu} / \mathrm{yr} \mathrm{ft}^{2}$. 


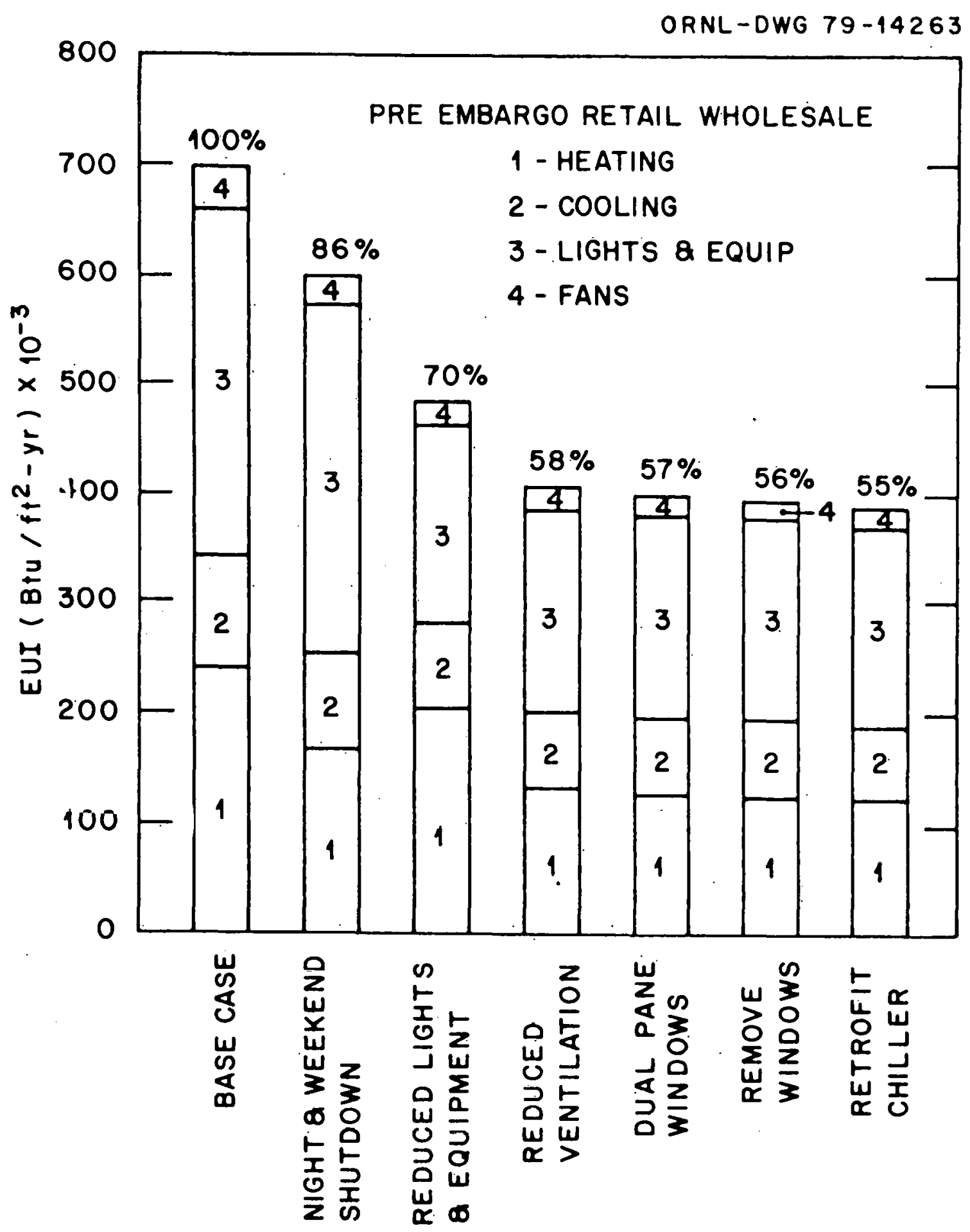

Fig. 15. Results of conservation measures - pre-embargo retail building. 


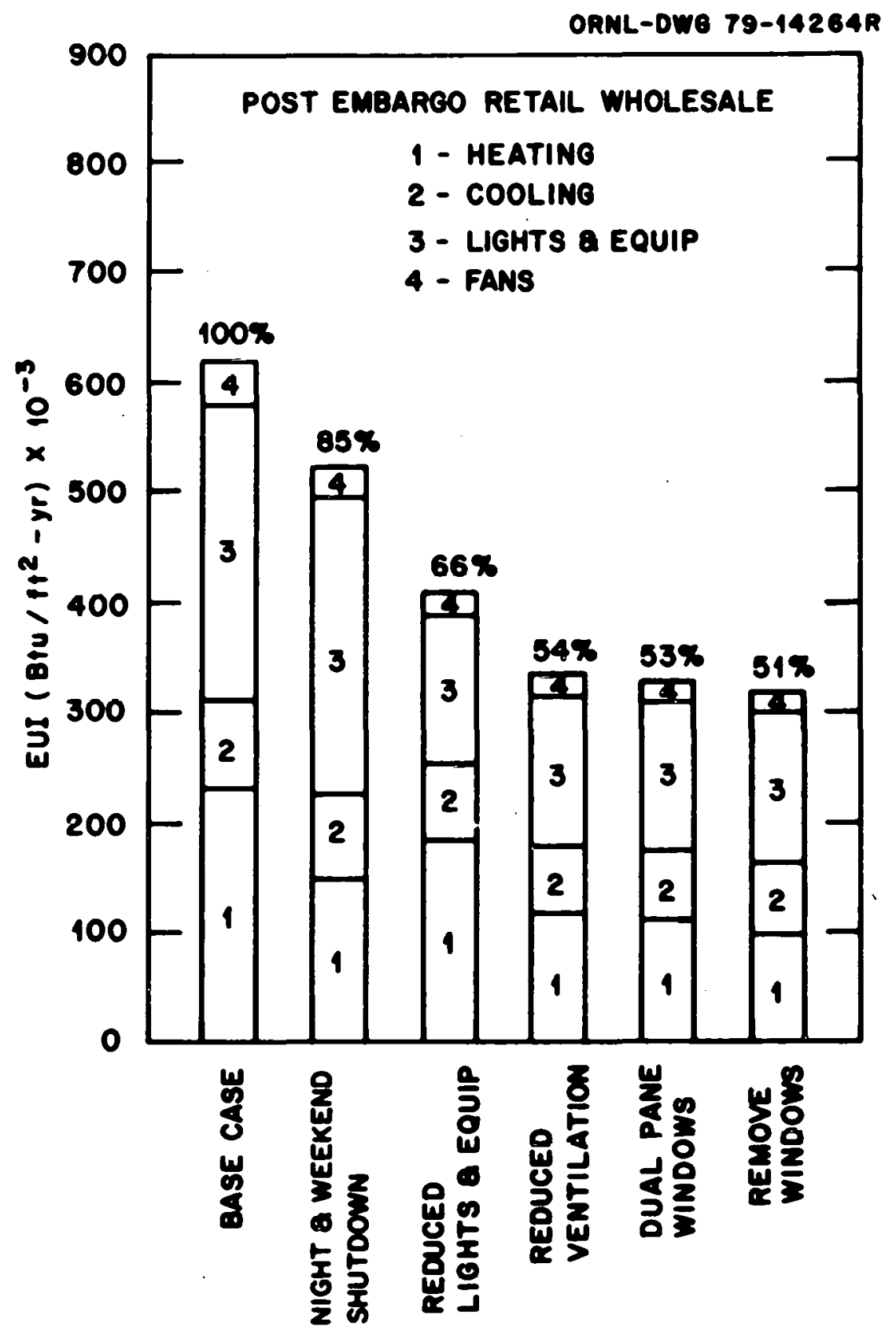

Fig. 16. Results of conservation measures - post-embargo retail bu1lding. 
The first modification consisted of shutdown of the cafeteria and department store systems during unoccupied times which resulted in a decrease in energy use of $12.9 \%$. As with previous cases, a low limit thermostat set at $40^{\circ} \mathrm{F}$ was used in the stores where system shutdown was employed. Reducing lighting levels from 7 to 3 watts/ft ${ }^{2}$ in the grocery and department stores and from 3 to 1.5 watts $/ \mathrm{ft}^{2}$ in the cafeteria saved $18.9 \%$ of the base energy consumption. Reducing the ventilation rates in the various stores resulted in an energy savings of $12.9 \%$.

The windows were all located on the south wall of the buildings and two modifications were employed on the windows. Replacing the single pane windows with double pane windows decreased the energy consumption by $1.2 \%$. The final modification consisted of completely removing the windows (replaced by walls) which produced a savings of approximately $0.6 \%$.

\section{SUMMARY OF RESULTS}

The four building types represented in this study consumed a total of 6.9 Quads of energy in 1975. Assuming all buildings of these types to be represented by the pre-embargo design reported herein, energy savings of 1.4 Quads could be produced by employing thermostat setback in all buildings. The corresponding savings for the post-embargo design would be 1.0 Quads. Including all low cost conservation measures considered (thermostat setback, reduced lighting, ventilation, reset controls, etc.) can potentially produce energy savings of 3.0 and 2.0 Quads for the pre- and post-embargo designs, respectively. Energy savings for these measures are primarily from space heating in which fossil fuel predominates, 
with smaller savings from lighting and cooling. Consequently, of the total energy saved approximately $80 \%$ is fossil energy and $20 \%$ electricity. The potential savings of the entire commercial sector through relatively low-cost energy conservation measures is approximately $35 \%$ assuming all other building types show similar characteristics to those examined in this study. These savings, however should represent an upper limit because of a number of bulldings which have already incorporated some energy conservation measures.

Results of this study will be utilized in the ORNL engineering/ economic model for the prediction of future energy use in commercial buildings. In this model, decisions involving the implementation of energy conservation measures must be made both in new construction and through retrofit in existing buildings based on economic justification from a life-cycle cost analysis. The curves of energy savings as a function of capital investment (Figs. 17-24) will be combined with similar curves produced by Lyman ${ }^{4}$ which involve HVAC modifications such as exhaust air heat recovery, total energy systems, double bundle exchangers, solar energy, etc. The use of these curves will allow the determination of the payback period hased on energy savings for each increment of capital investment considered.

\section{ENERGY SAVINGS AND CAPITAL COSTS}

The impact of various energy conservation measures has been discussed in the previous sections. The capital cost of each measure was estimated based on cost estimating manuals, ${ }^{8}$ manufacturer's data and 


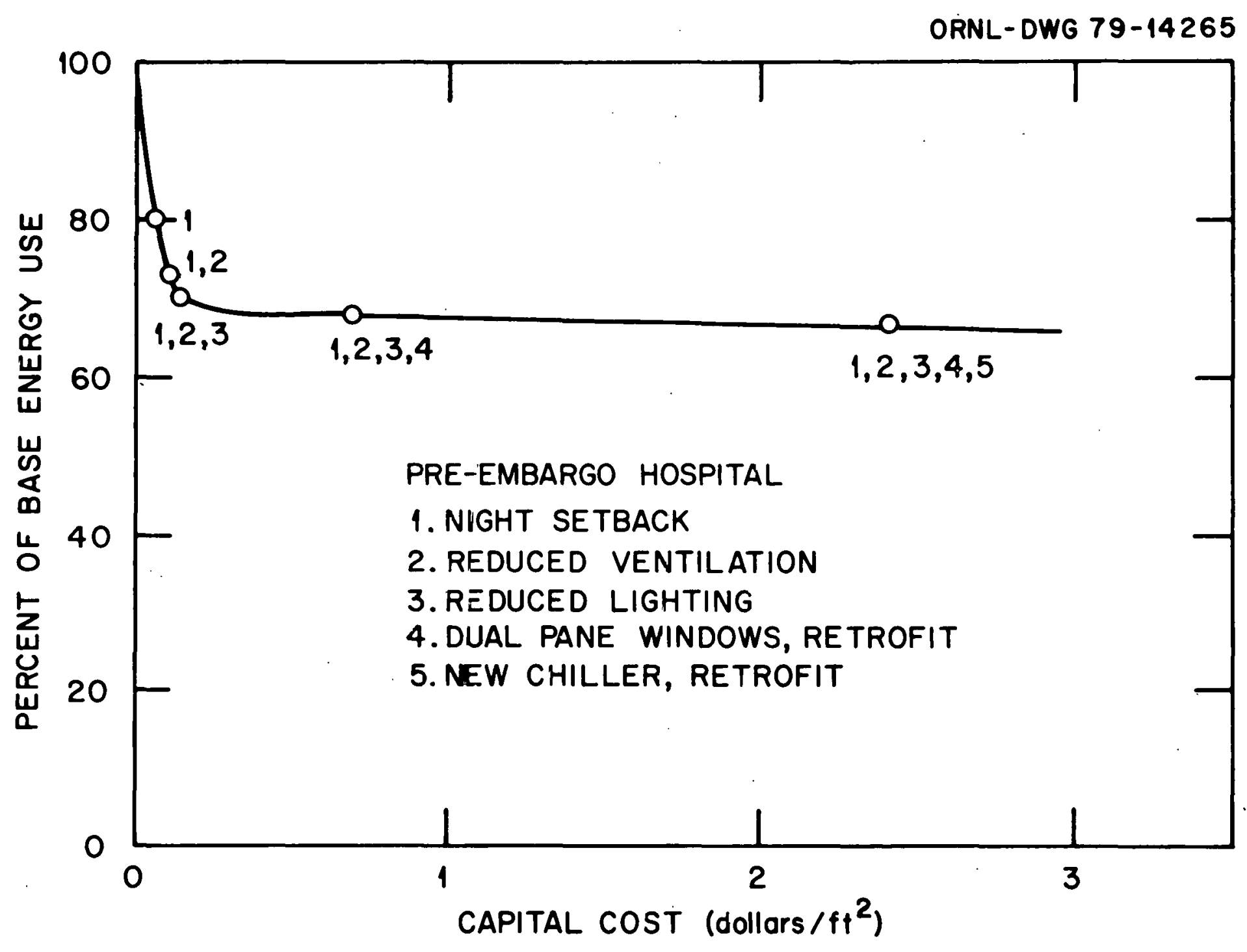

Fig. 17. Energy savings vs capital costs - pre-embargo hospital. 


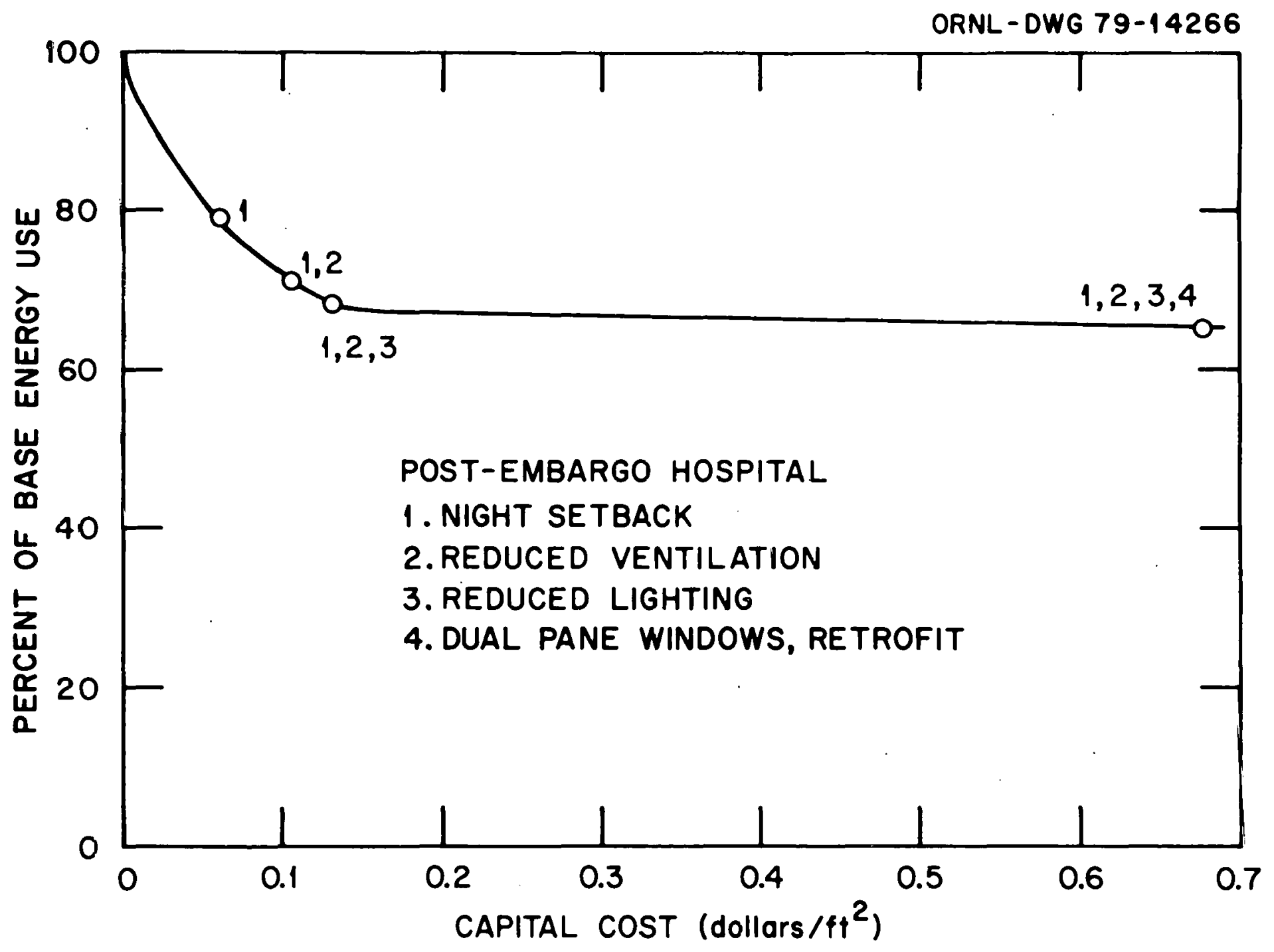

Fig. 18. Energy savings vs capital costs - post-embargo hospital. 


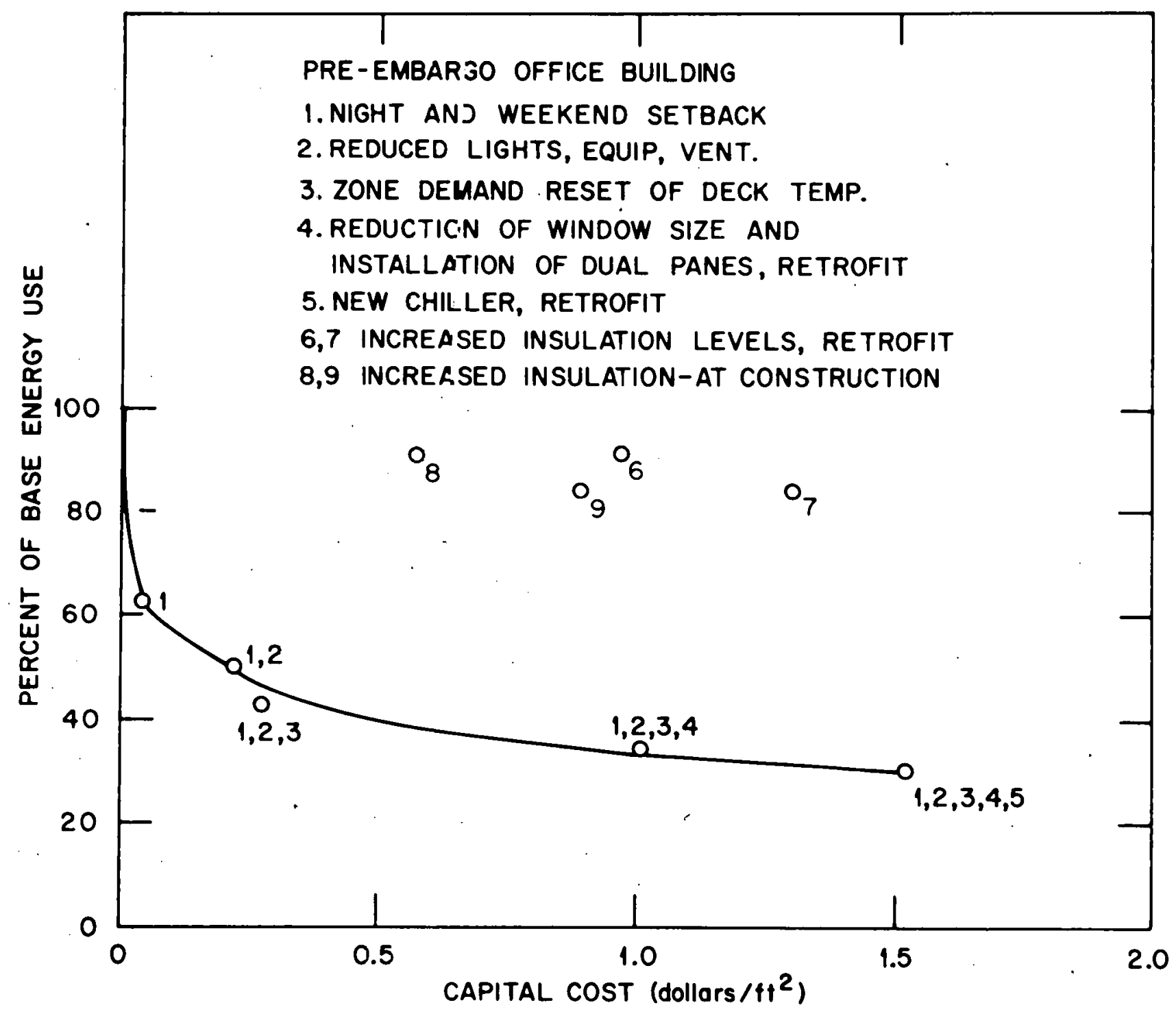

Fig. 19. Energy savings vs capital costs - pre-embargo office building. (For a discussion of points 6-9, see Appendix) 
ORNL-DWG 79-14268

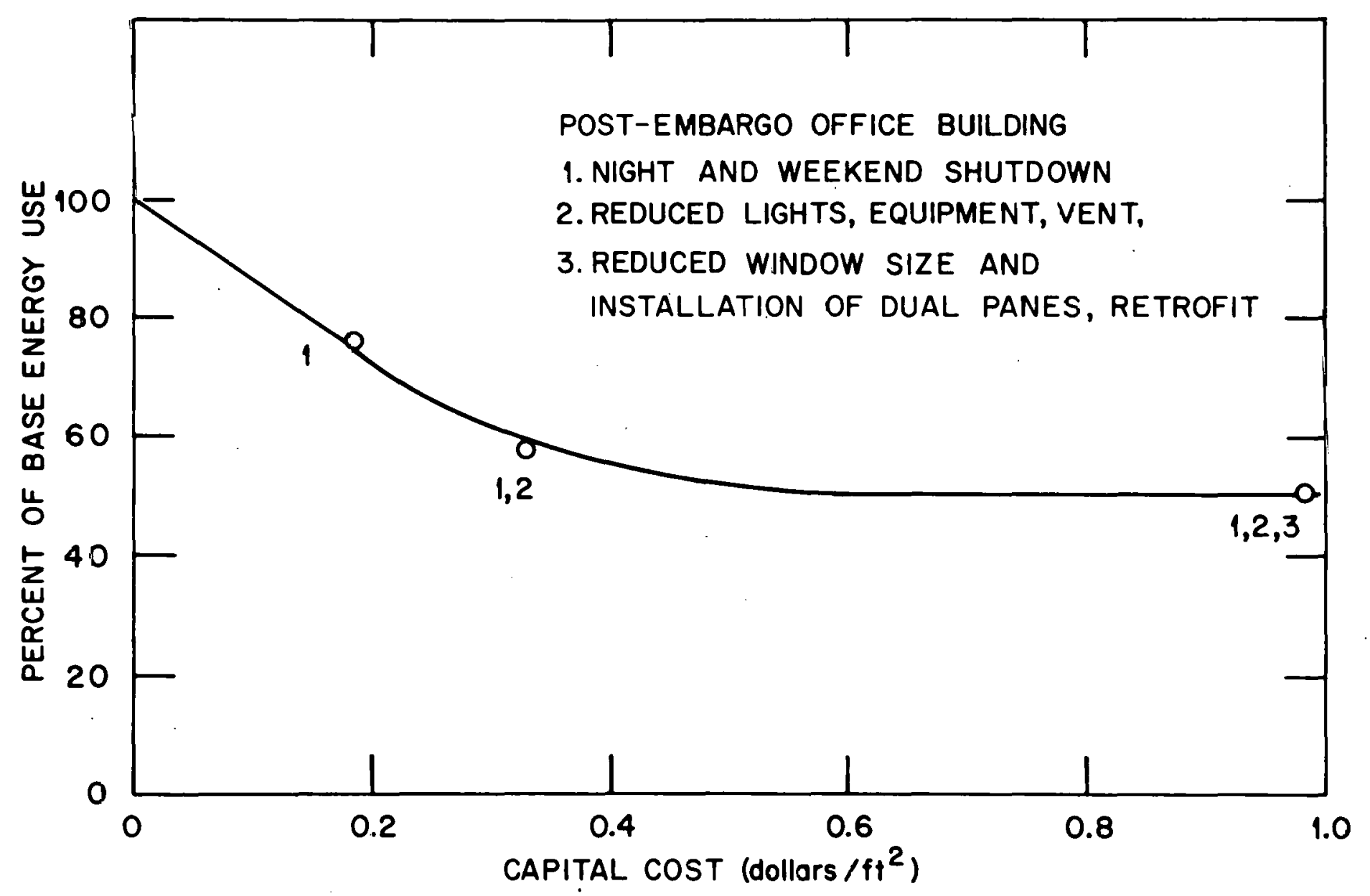

Fig. 20. Energy savings vs capital costs - post-embargo office building. 


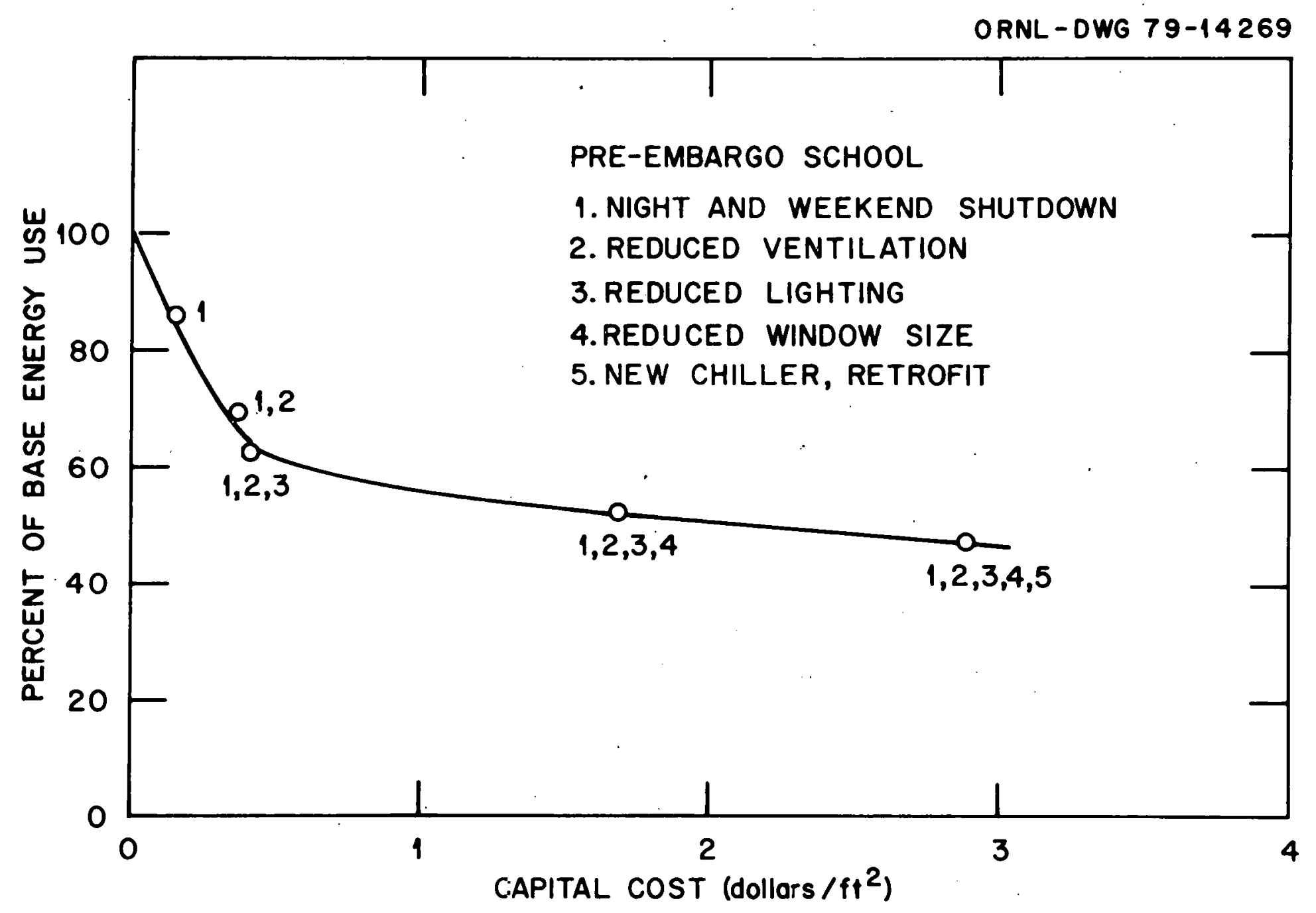

Fig. 21. Energy savings vs capital costs - pre-embargo educational facility. 


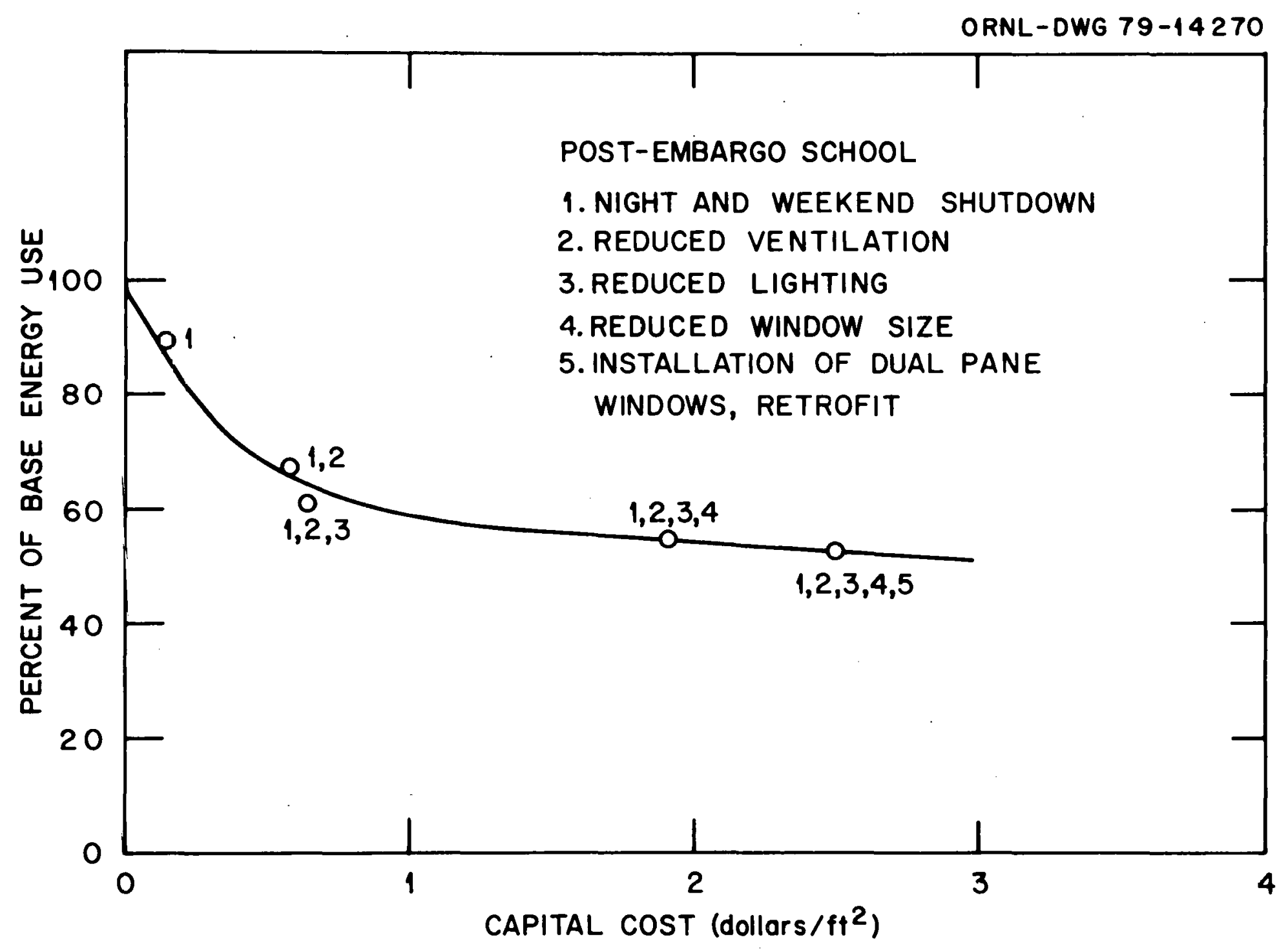

Fig. 22. Energy savings vs capital costs - post-embargo educational facility. 


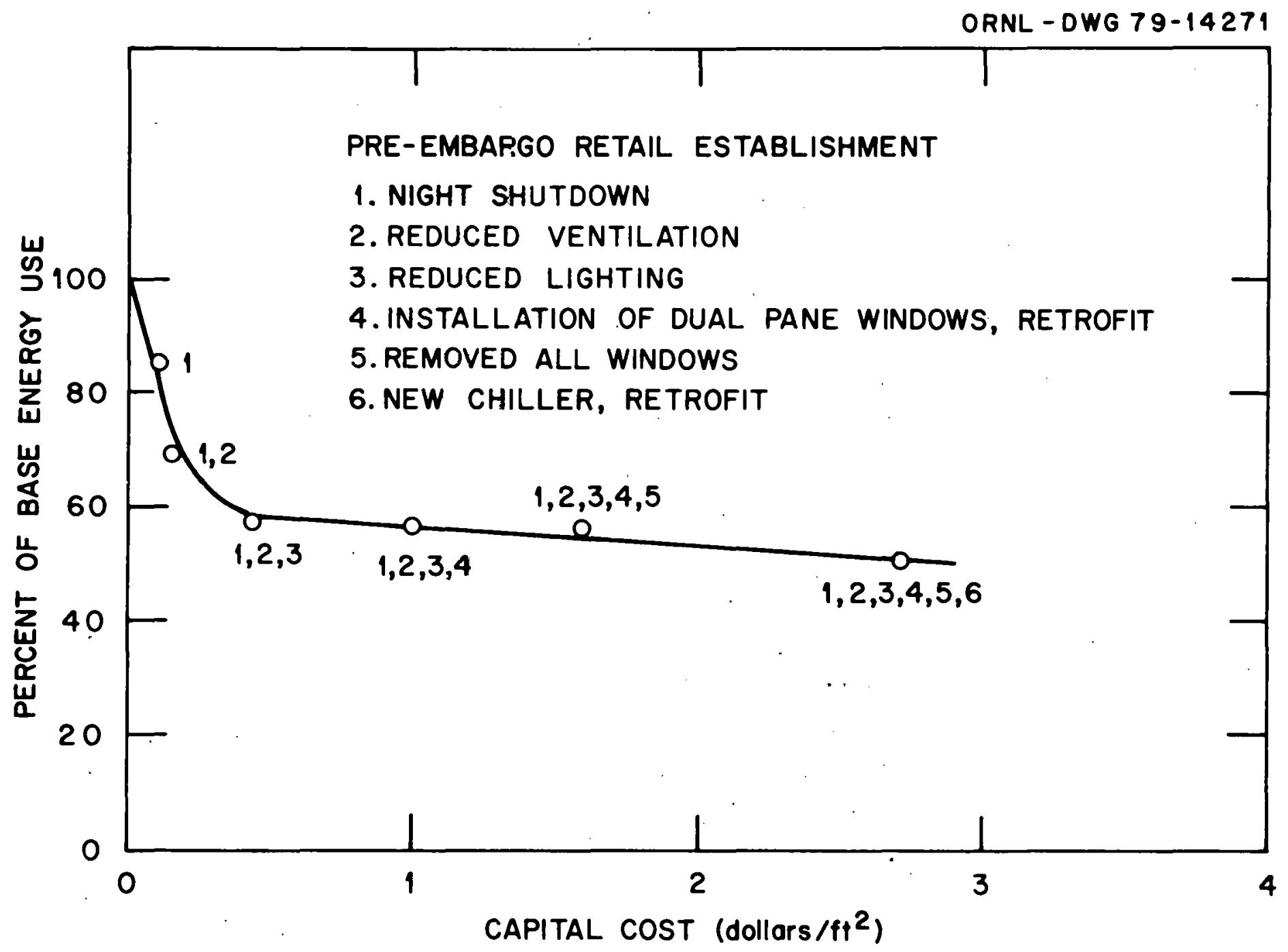

Fig. 23. Energy savings vs capital costs - pre-embargo retail building. 


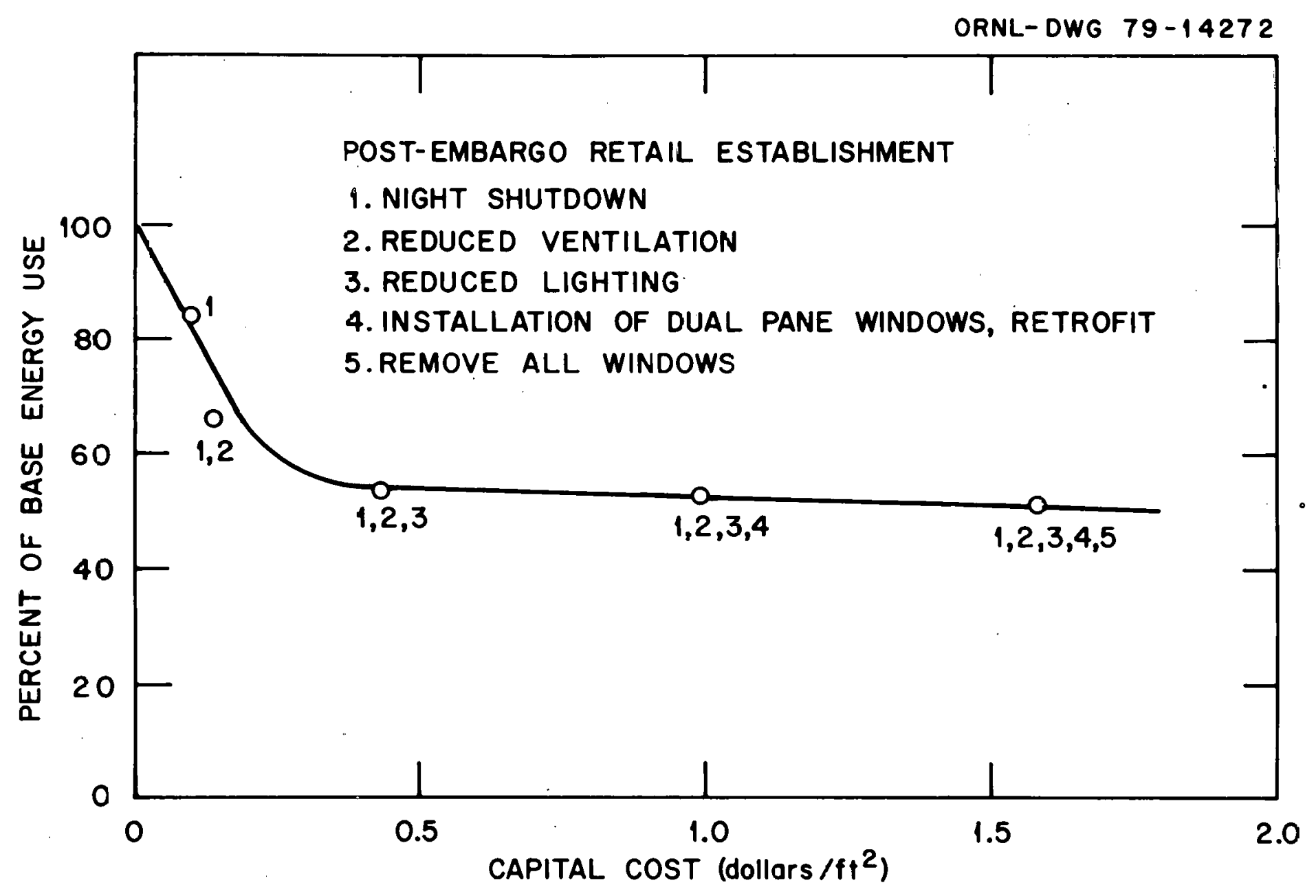

Fig. 24. Energy savings vs capital costs - post-embargo retail building. 
discussions with ORNL estimating personnel. Costs include both equipment and labor. However, $25 \%$ was added to the labor cost to account for contingencies.

The costs of each energy conservation measure are heavily dependent in some cases on the type and number of HVAC systems. Therefore a considerable difference can be seen in the costs of night setback, reducing ventilation, adding economizers, and including demand reset of deck temperatures depending on the number of systems involved. It should be remembered that the costs presented here are for the modifications applied to the particular number and types of HVAC systems that were employed in the specific buildings considered.

Costs associated with night setback included the purchase and installation of time clocks for each system. For the reduction of ventilation, costs included the purchase and installation of sheaves and belts to operate the fan at a lower speed. In cases, however, when the lower speed ytuduced a eignifirant decrease in motor efficiency, a new, smaller motor was included in the costs. Once the equipment was in place, a labor charge was then added to balance the system.

Costs associated with delamping included both labor and the costs of determining where and how many bulbs can be removed.

Replacement costs of a chiller included purchase, removal of the old chiller and installation of the new one. It should be noted that the required capacity and cost of the new chiller is lower, both due to increased efficiency and to previously incorporated conservation measures which reduce the peak cooling load. The.replacement of single pane windows with dual-pane units involves the removal of old windows and the 
purchase and installation of new units. When the window size was decreased the cost of blocking up a portion of the window opening was included.

Figures 17 through 24 show energy savings vs capital costs for the various conservation measures for each of the building types. Both costs and energy savings are cumulative moving from left to right and down on the curves. It should be noted that all practical combinations of conservation measures are not included in these curves. For example, dual-pane windows could be included in the original design of a postembargo building at a significant cost savings over the retrofit option which is the only case considered in this study. The optimum expenditure can be determined by a life cycle cost analysis and is dependent on the cost of the various forms of energy and their estimated escalation rates. 
REFERENCES

1. ASHRAE Standard 90-75, "Energy Conservation in New Building Design," American Society of Heating, Refrigerating, and Air-Conditioning Engineers, Inc., New York, New York, 1975.

2. J. R. Jackson and W. S. Johnson, "Commercial Energy Use: A Disaggregation by Fue1, Building Type, and End Use," Oak Ridge National Laboratory, ORNL/CON 14, Feb. 1978.

3. NECAP-NASA Energy-Cost Analysis Program, Part I - User's Manual and Part II - Engineering Manual, R. H. Henninger, ed., NASA CR-2590, Sept. 1975.

4. R. E. Lyman, "Energy and Cost Analysis of Commercial HVAC Equipment: Offices and Hospitals," Oak Ridge National Laboratory, ORNL/CON-32.

5. ASHRAE Standard 62-73, "Standards for Natural and Mechanical Ventilation," American Society of Heating, Refrigerating, and AirConditioning Engineers, Inc., New York, New York, 1973.

6. ASHRAE Guide and Data Book-Applications, American Society of Heating, Refrigerating, and Air-Conditioning Engineers, Inc., New York, New York, 1972 .

7. Uniform Buizding Code, International Conference of Building Officials, Whittier, California, 1976.

8. Building Construction Cost Data - 1975, Robert S. Means Co., Durbury, Mass. 1974. 


\section{APPENDIX}

An additional, related study was undertaken to determine the effect of various amounts of wall and roof insulation on energy use and on capital costs for retrofit to existing buildings. The pre-embargo office building was used in this study with insulation added prior to the incorporation of any of the other energy conservation measures discussed in the report.

The base case insulation levels for this building were $1^{\prime \prime}$ of insulation in the roof and no insulation in the walls. The next case considered was $3^{\prime \prime}$ of insulation in the roof and $1^{\prime \prime}$ in the outside walls. The final condition consisted of 4 " of roof insulation and 3 " of wall insulation.

The base.case generally does not meet the ASHRAE 90-75 standard while the second case generally meets the standard in regions having less than 4800 heating degree days. The case of maximum insulation in this building will meet ASHRAE 90-75 in regions of the country having less than 6800 heating degree days.

Figure 25 shows the effect of the ovcrall liear transfer coefficient* on energy use for this building located in Kansas City. The primary effect, as noted, is on the energy required for space heating with minimal effect on space cooling. This is typical of commercial buildinge whcre space cooling is primarily dependent on window solar loads and internal lodds such as occupants, 11ghts, and equipment.

\footnotetext{
${ }^{*}$ An area weighted average of walls, windows, and doors.
} 


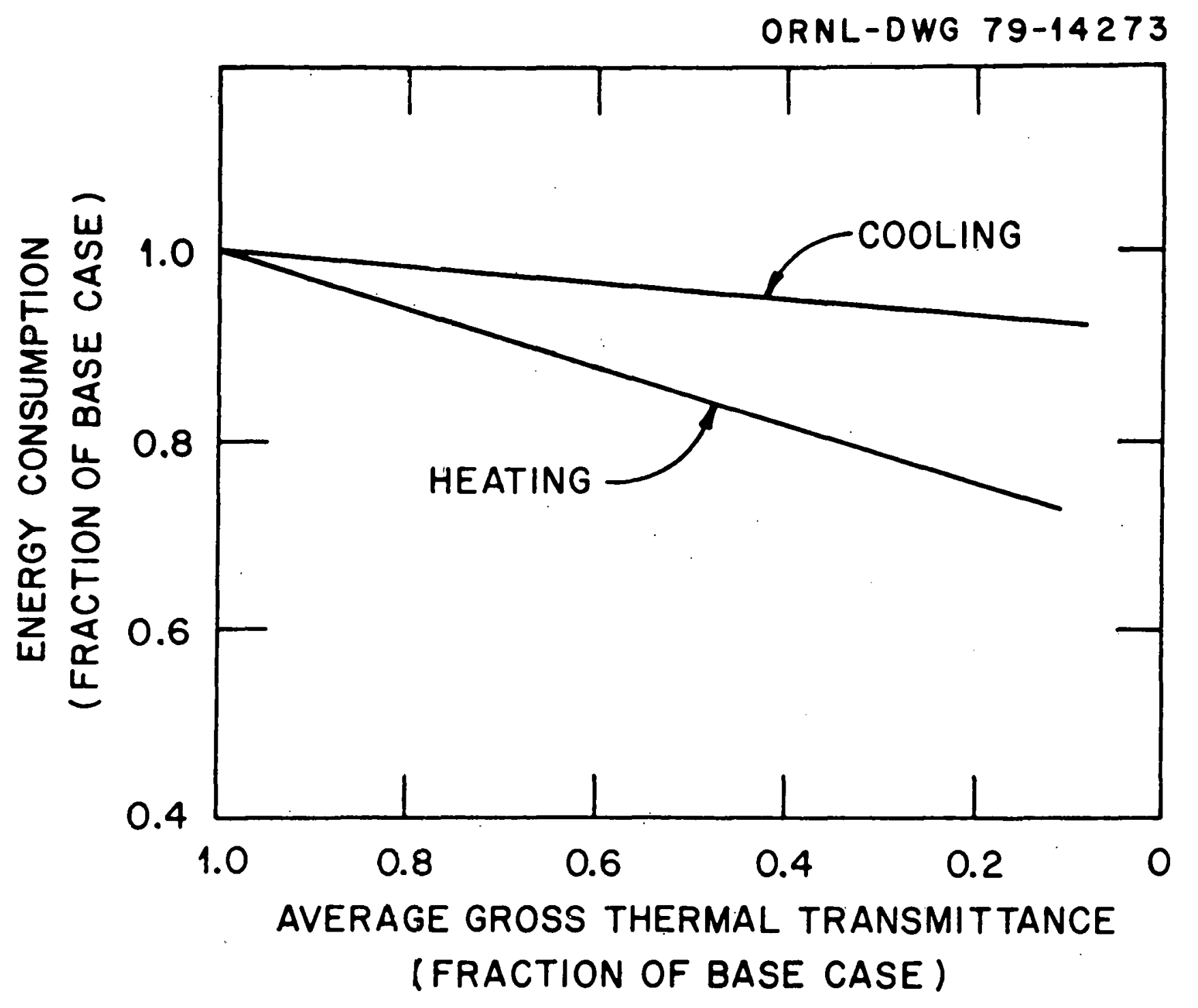

Fig. 25. Ener:zy consumption vs shell thermal resistance. 
Energy savings as a function of capital costs for the two levels of insulation relative to the base case are given on Fig. 19 which also shows the other encrgy conservation measures for the pre-embargo office building. Costs are shown for both retrofit to an existing building and for installation of the insulation when the building is constructed. A significant cost difference is noted.

Inclusion of the insulation when the building is constructed incurs only the direct additional costs for materials and labor. The retrofit option involves additional costs, however. Wa1l insulation is incorporated by the nailing of furring strips on the walls and, after the insulation is installed between the strips, a covering of paneling is installed. To add roof insulation through retrofit it is necessary to first remove the built-up roofing and install the insulation above the deck before adding a new built-up roof. The addition of insulation below the roof deck is not recommended because of severe moisture problems which may occur.

Based on economic considerations possibly the only cost effective option to add roof insulation would be if a roof replacement is needed anyway . 
THIS PAGE WAS INTENTIONALLY LEFT BLANK 
ORNL/CON-39

INTERNAL DISTRIBUTION

1. L. A. Abbatiello

2. H. G. Arnold

3. M. Baker

4. M. Bender

5. W. J. Boegly, Jr .

6. F. D. Boercker

7. R. S. Carlsmith

8. J. E. Christian

9. K. R. Corum

10. G. A. Dailey

11. R. C. DeVault

12. R. D. Ellison

13. P. D. Fairchild

14. W. Fulkerson

15. R. E. Gant

16. V. O. Haynes

17. E. A. Hirst

18. R. B. Honea

19. W. S. Johnson
20. S. I. Kaplan

21. J. O. Kolb

22-26. A. S. Loeb1

27. T. S. Lundy

28. R. E. Minturn

29-39. W. R. Mixon

40. D. L. O'Neal

41. F. E. Pierce

42. G. D. Pine

43. G. Samuels

44. I. Spiewak

45. D. J. Wilkes

46. Biology Division Library

47-48. Central. Research Library

49. Document Reference Section

50-51. Energy Information Library

52. Laboratory Records, (RC)

53-55. Laboratory Records Department

56. ORNL Patent Office

EXTERNAL DISTRIBUTION

57. Institute of Energy Analysis, ORAU - Library

58. Office of Assistant Manager, Energy Rësearch and Development, DOE-ORO

59-86. Technical Information Center, DOE, P. 0. Box 62, Oak Ridge, TN 37830

87-7000. External Energy Conservation Distribution Mailing List and Extra Copies to M. Stanford 4500N, Room H-32. 